\title{
Camerobiid mites (Acariformes: Raphignathina: Camerobiidae) inhabiting epiphytic bromeliads and soil litter of tropical dry forest with analysis of setal homology in the genus Neophyllobius
}

\author{
Ricardo PAREDES-LEÓN ${ }^{1, *}$, Angélica María CORONA-LÓPEZ², \\ Alejandro FLORES-PALACIOS ${ }^{3} \&$ Víctor Hugo TOLEDO-HERNÁNDEZ $^{4}$ \\ ${ }^{1,2,3,4}$ Centro de Investigación en Biodiversidad y Conservación (CIByC), Universidad Autónoma del \\ Estado de Morelos, Avenida Universidad 1001, Col. Chamilpa, C.P. 62209, Cuernavaca, Morelos, México. \\ *Corresponding author: ricardo.paredes@uaem.mx \\ ${ }^{2}$ Email: acorona@uaem.mx \\ ${ }^{3}$ Email: alejandro.florez@uaem.mx \\ ${ }^{4}$ Email: victor.toledo@uaem.mx \\ ${ }^{1}$ urn:Isid:zoobank.org:author:3A3A9078-178C-41AD-8520-B2E72BDFC21C \\ ${ }^{2}$ urn:1sid:zoobank.org:author:D9D501D6-5883-4C9A-877D-5567149BC542 \\ ${ }^{3}$ urn:lsid:zoobank.org:author:DF49E2C9-D57A-4AF9-92AB-AD3C828A97D1 \\ ${ }^{4}$ urn:lsid:zoobank.org:author:EEB41EAF-BA41-4EEF-BA11-3FCFAF37EE93
}

\begin{abstract}
A survey of the camerobiid mites living on epiphytic bromeliads and the forest floor of a Mexican tropical dry forest was carried out. We found three new species of the genus Neophyllobius, which are described in this paper; the first two, namely $N$. cibyci sp. nov. and N. tepoztlanensis sp. nov., were both found inhabiting bromeliads (Tillandsia spp.) and living on two tree species (Quercus obtusata and Sapium macrocarpum); the third, N. tescalicola sp. nov., was found in soil and litter under $Q$. obtusata. These three new species can be differentiated from other species in the genus by a combination of morphological characters in adult females, mainly those setae on femora and genua I. The idiosoma and leg setal ontogeny of a camerobiid mite is presented for the first time in this paper, illustrating chaetotaxic notations and their relative positions in $N$. cibyci sp. nov. larva, protonymph and adults (female and male), and establishing setal homologies among instars. Setal homology with other species in the cohort Raphignathina is briefly discussed. Additionally, a compilation and an identification key to all known species of camerobiid mites in Mexico is provided.
\end{abstract}

Keywords. Acari, chaetotaxy, Mexico, predator, Prostigmata, tree canopy, Tillandsia spp.

Paredes-León R., Corona-López A.M., Flores-Palacios A. \& Toledo-Hernández V.H. 2016. Camerobiid mites (Acariformes: Raphignathina: Camerobiidae) inhabiting epiphytic bromeliads and soil litter of tropical dry forest with analysis of setal homology in the genus Neophyllobius. European Journal of Taxonomy 202: 1-25. http:// dx.doi.org/10.5852/ejt.2016.202 


\section{Introduction}

The family Camerobiidae Southcott, 1957 (Acariformes: Prostigmata: Raphignathina: Raphignathoidea) comprises about 161 species in seven genera of predatory mites (Fan \& Walter 2011; Zhang et al. 2011; Khanjani et al. 2012a, 2012b, 2013, 2014; Akyol 2013; Khanjani \& Hoseini 2013; Zeity \& Gowda 2013; Uluçay \& Koç 2014). Camerobiids are usually found in different microhabitats like humus, tree bark, vegetation or inside epiphytes in temperate and tropical ecosystems. Some camerobiid species feed on plant pests such as scale insects (Coccoidea), plant-parasitic mites (Eriophyidae and Tenuipalpidae) and on other small mites that scavenge or feed on fungi on plant surfaces (Tarsonemidae and Tydeidae) (McGregor 1950; De Leon 1967; Bolland 1983; Gerson et al. 2003; Walter et al. 2009).

Neophyllobius Berlese, 1886 species have world-wide distribution, and the genus is the richest in Camerobiidae with more than 100 species. The genus was revised by Bolland (1991) and later works mainly include species descriptions (e.g., Koç \& Ayyildiz 1996; Bolland 2001; Khanjani \& Ueckermann 2006; Khanjani et al. 2010; Uluçay \& Koç 2014). Like many other groups of mites, there is insufficient knowledge regarding their ecology and ontogeny which, in turn, restricts our knowledge of habitat specificity and the identification of homologies among species. Also, many descriptions of camerobiid mites are based on a single specimen because they are usually found singly or in low numbers (Bolland 1986), and rarely is setal nomenclature detailed.

Members of Raphignathoidea generally include four active postembryonic instars: larva, protonymph, deutonymph and adult (Walter et al. 2009). However, in Neophyllobius it is questioned whether the life cycle includes one nymphal instar instead of two. Protonymphs are frequently found, but deutonymphs have been mentioned briefly only in a few species, for example $N$. saxatilis Halber, 1938, N. ambulans Meyer, 1962, N. gonzali Zaher \& Gomaa, 1979, N. aesculi Bolland, 1983, N. ceratoniae Bolland, 1991, N. dichantii Bolland, 1991, N. muscantribii Bolland, 1991 and N. piniphilus Bolland, 2001 (Bolland 1983, 1991, 2001). Only the deutonymphs of the last two species has been partially illustrated (Bolland 1983, 1991). Because of the scarcity of specimens the distinction between deutonymph and adult female is not always clear. Besides, two types of protonymphs (male and female) has been recognized at least in N. piniphilus (Bolland 2001).

The family Camerobiidae in Mexico comprises 13 species of Neophyllobius (Bolland 1991) (Table 1). This number is clearly low, suggesting that the group is under-represented, and shows that camerobiid mites have been reported throughout tropical and northern areas and in a variety of different habitats (inside epiphytes, tree bark or in the forest floor).

Analysis of leg chaetotaxy for different instars in rich groups, like the genus Neophyllobius, could provide systematic and phylogenetic clues for a better understanding of the groups at different hierarchical levels (Swift 2001), and may be helpful in distinguishing between lineages (Norton 1977). It is important to homologize the setal organs in the different species and among different instars because to ignore the homology and only take into account the numerical formulas in descriptions of new taxa is not phylogenetically informative. In the Camerobiidae, Grandjean's idiosomal chaetotaxy system was firstly applied by Kethley (1990), whereas the leg chaetotaxy system was implemented in adult females belonging to Acamerobia inflatus Fan \& Walter, 2011 (Fan \& Walter 2011). However, leg chaetotaxy is frequently omitted in most recent species descriptions, with a few noteworthy exceptions (e.g., Khanjani et al. 2013, 2014).

In this paper, we provide descriptions of three new species of Neophyllobius: two that have been found exclusively on epiphytic bromeliads and one on soil litter in Mexico. An identification key to females of all the species of Neophyllobius in Mexico is provided. The ontogeny of idiosoma and leg setation, setal notations (chaetotaxy) and their relative positions on the podomeres are presented and illustrated for one of these new species. 
PAREDES-LEÓN R. et al., New species of camerobiid mites and setal homology in Neophyllobius

Table 1. Species of Neophyllobius Berlese, 1886 recorded in Mexico.

\begin{tabular}{|c|c|c|c|c|}
\hline SPECIES & LOCALITY & HABITAT & REFERENCE & REMARKS \\
\hline $\begin{array}{l}\text { N. mexicanus McGregor, } \\
1950\end{array}$ & $\begin{array}{l}\text { Mexico, intercepted at } \\
\text { Brownsville, TX }\end{array}$ & On avocado budwood & McGregor (1950) & Unknown locality \\
\hline $\begin{array}{l}\text { N. quadrisetosus De Leon, } \\
1958\end{array}$ & $\begin{array}{l}\text { SONORA: Guaymas, } \\
\text { intercepted at Nogales }\end{array}$ & Soil from cactus & De Leon (1958) & \\
\hline \multirow{6}{*}{$\begin{array}{l}\text { N. trisetosus De Leon, } \\
1958\end{array}$} & OAXACA: Oaxaca & Quercus sp. & De Leon (1958) & \\
\hline & $\begin{array}{l}\text { OAXACA: Siete } \\
\text { Cabrillas }\end{array}$ & Quercus sp. & & \\
\hline & $\begin{array}{l}\text { OAXACA: } \\
\text { Tamazulapan }\end{array}$ & Unknown tree & & \\
\hline & $\begin{array}{l}\text { MICHOACAN: near } \\
\text { Quiróga }\end{array}$ & & & \\
\hline & $\begin{array}{l}\text { NAYARIT: Santa } \\
\text { María del Oro }\end{array}$ & & & \\
\hline & $\begin{array}{l}\text { NAYARIT: Ixtlán del } \\
\text { Río }\end{array}$ & & & \\
\hline N. farrieri De Leon, 1958 & $\begin{array}{l}\text { OAXACA: Puenta } \\
{[\text { sic }] \text { de Nejapa }}\end{array}$ & Spanish moss & De Leon (1958) & $\begin{array}{l}\text { The common name "Spanish } \\
\text { moss" is commonly used to } \\
\text { refer to Tillandsia usneoides } \\
\text { (L.) L. }\end{array}$ \\
\hline $\begin{array}{l}\text { N. inequalis De Leon, } \\
1958\end{array}$ & $\begin{array}{l}\text { VERACRUZ: } \\
\text { Veracruz }\end{array}$ & $\begin{array}{c}\text { Erythrina sp., Terminalia } \\
\text { catappa } \mathrm{L} .\end{array}$ & De Leon (1958) & \\
\hline N. equalis De Leon, 1958 & $\begin{array}{l}\text { NAYARIT: Navarrete } \\
\text { SAN LUIS POTOSI: } \\
\text { near Valles }\end{array}$ & Guazuma sp. & De Leon (1958) & $\begin{array}{l}\text { According to De Leon } \\
\text { (1958) and Bolland (1991), } \\
\text { it is open to doubt whether } \\
\text { the specimens recorded in } \\
\text { San Luis Potosí belong to } \\
\text { this species }\end{array}$ \\
\hline $\begin{array}{l}\text { N. consobrinus De Leon, } \\
1958\end{array}$ & $\begin{array}{l}\text { CHIAPAS: Tuxtla } \\
\text { Gutiérrez }\end{array}$ & Jaquinia pungens A.Gray & De Leon (1958) & \\
\hline N. lobatus De Leon, 1958 & NAYARIT: San Blas & From "guasamolleta" & De Leon (1958) & $\begin{array}{l}\text { On Guasa molleta sensu } \\
\text { Bolland (1991) }\end{array}$ \\
\hline \multirow[t]{2}{*}{$\begin{array}{l}\text { N. marginatus De Leon, } \\
1958\end{array}$} & $\begin{array}{l}\text { NAYARIT: Ixtlán del } \\
\text { Río }\end{array}$ & Asteraceae & De Leon (1958) & \\
\hline & $\begin{array}{l}\text { NAYARIT: nine miles } \\
\text { west of Tepic }\end{array}$ & Quercus sp. & & \\
\hline $\begin{array}{l}\text { N. longulus De Leon, } \\
1958\end{array}$ & $\begin{array}{l}\text { OAXACA: Matías } \\
\text { Romero }\end{array}$ & Calophyllum sp. & De Leon (1958) & \\
\hline $\begin{array}{l}\text { N. curtipilus De Leon, } \\
1958\end{array}$ & $\begin{array}{l}\text { CHIAPAS: Tuxtla } \\
\text { Gutiérrez }\end{array}$ & $\begin{array}{l}\text { Cordia dentata Poir., } \\
\text { Guazuma tomentosa } \\
\text { Lam., } \\
\text { Rhus schideana Schltdl., } \\
\text { Lonchocarpus rugosus } \\
\text { Benth., } \\
\text { Quercus sp., and } \\
\text { avocado }\end{array}$ & De Leon (1958) & $\begin{array}{l}\text { De Leon first (1958) named } \\
\text { this species as } N \text {. curtipilus } \\
\text { (p. } 175,178,180) \text {, but later } \\
\text { the name was misspelled as } \\
N . \text { curtipilis (p.181) } \\
\text { Also, Bolland (1991) } \\
\text { misspelled it as } N . \text { curtipilis }\end{array}$ \\
\hline \multirow[t]{2}{*}{$\begin{array}{l}\text { N. spatulus De Leon, } \\
1958\end{array}$} & NAYARIT: Tepic & $\begin{array}{l}\text { Two undetermined } \\
\text { species of Asteraceae }\end{array}$ & De Leon (1958) & $\begin{array}{l}\text { The type specimens are lost } \\
\text { (Bolland 1991) }\end{array}$ \\
\hline & $\begin{array}{l}\text { OAXACA: km post } \\
\text { 666, Route } 190 \text { north } \\
\text { of Tehuantepec }\end{array}$ & A Malpighiaceae shrub & & \\
\hline
\end{tabular}




\begin{tabular}{|c|c|c|c|c|}
\hline SPECIES & LOCALITY & HABITAT & REFERENCE & REMARKS \\
\hline N. deleoni Bolland, 1991 & $\begin{array}{l}\text { JALISCO: route } 35, \\
18 \text { miles southeast of } \\
\text { Guadalajara }\end{array}$ & Unknown & Bolland (1991) & $\begin{array}{l}\text { Originally described as } \\
\text { Neophyllobius horridus } \\
\text { by De Leon (1958) but as } \\
\text { the name was preoccupied, } \\
\text { Bolland (1991) re-named it }\end{array}$ \\
\hline \multicolumn{5}{|c|}{ DOUBTFUL AND UNDETERMINED SPECIMENS } \\
\hline \multirow[t]{5}{*}{ Neophyllobius spp. } & $\begin{array}{l}\text { CAMPECHE: } \\
\text { Calakmul }\end{array}$ & Soil litter & $\begin{array}{l}\text { Vázquez et al. } \\
\text { (2011) }\end{array}$ & \\
\hline & $\begin{array}{l}\text { CAMPECHE: Zoh- } \\
\text { Laguna }\end{array}$ & Soil litter & & \\
\hline & $\begin{array}{l}\text { QUINTANA ROO: } \\
\text { Reserva de la Biósfera } \\
\text { de Sian Ka'an }\end{array}$ & Soil litter & & \\
\hline & $\begin{array}{l}\text { QUINTANA ROO: } \\
\text { Bahía de Chetumal }\end{array}$ & Leaf litter and mangrove & $\begin{array}{c}\text { Vázquez- } \\
\text { González (2008) }\end{array}$ & \\
\hline & $\begin{array}{l}\text { MORELOS: Mpio. } \\
\text { Tepoztlán: "derrame } \\
\text { lávico del volcán } \\
\text { Chichinautzin" }\end{array}$ & Tillandsia spp. & This study & $\begin{array}{l}\text { See comments about } \\
\text { Camerobia } \mathrm{sp.}\end{array}$ \\
\hline Camerobia sp. & $\begin{array}{l}\text { MORELOS: Mpio. } \\
\text { Tepoztlán: "derrame } \\
\text { lávico del volcán } \\
\text { Chichinautzin" }\end{array}$ & Tillandsia spp. & $\begin{array}{l}\text { Palacios-Vargas } \\
\text { (1982) }\end{array}$ & $\begin{array}{l}\text { All the species of } \\
\text { Camerobia Southcott, } \\
1957 \text { are not distributed } \\
\text { throughout the Americas. } \\
\text { We reviewed six adult } \\
\text { specimens from this series } \\
\text { (CNAC009249-009254) } \\
\text { and they are Neophyllobius }\end{array}$ \\
\hline Camerobiidae gen. et sp. & $\begin{array}{l}\text { MORELOS } \\
\text { VERACRUZ }\end{array}$ & $\begin{array}{l}\text { Tillandsia prodigiosa } \\
\text { (Lemaire) Baker }\end{array}$ & $\begin{array}{l}\text { Hoffmann \& } \\
\text { López-Campos } \\
\text { (2000) }\end{array}$ & $\begin{array}{l}\text { Undetermined genus and } \\
\text { species }\end{array}$ \\
\hline
\end{tabular}

\section{Material and methods}

This research was carried out in the tropical dry forest about $1 \mathrm{~km}$ south of San Andres de la Cal,

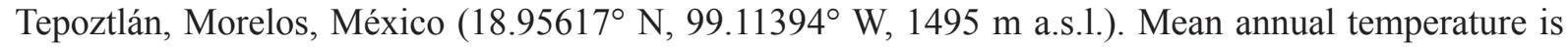
about $20.5^{\circ} \mathrm{C}$ and mean annual precipitation is $1091.8 \mathrm{~mm}$. The tropical dry forest in the study area has an open canopy with short tree species (maximum $16 \mathrm{~m}$ in hight); two forest units can be identified by plant composition and the parent rock of the soil (Cortés-Anzúres 2015; Vergara-Torres et al. 2010).

Sampling was done in the forest unit emerged on a lava flow; here, epiphytes are abundant (25 species) and the dominant tree species are Sapium macrocarpum Müll.Arg. (Euphorbiaceae), Ipomoea pauciflora M.Martens \& Galeotti (Convolvulaceae) and Quercus obtusata Bonpl. (Fagaceae), which together comprise $46 \%$ of tree individuals. The most abundant epiphytes are widespread bromeliads Tillandsia hubertiana Matuda and T. schiedeana Steud. (Bromeliaceae), which comprise $76 \%$ of all adult individuals (Cortés-Anzúres 2015).

Camerobiid mites were collected from two species of epiphytic plants (Bromeliaceae): Tillandsia hubertiana and T. schiedeana. Both bromeliads are xerophytic, but T. schiedeana has been deemed an atmospheric epiphyte (gray, narrow leaves that do not form an impounding tank) whereas T. hubertiana is a tank epiphyte (green, wide leaves that do form an impounding tank) (Ruiz-Cordova et al. 2014). T. hubertiana is endemic to Mexico (Espejo-Serna et al. 2004). Both bromeliads were collected from 
PAREDES-LEÓN R. et al., New species of camerobiid mites and setal homology in Neophyllobius

trunks or branches of two tree species: Quercus obtusata and Sapium macrocarpum. Quercus obtusata is an oak species endemic to Mexico (Arizaga et al. 2009). Additionally, soil litter samples were collected from around the base of the trunk of both Q. obtusata and S. macrocarpum.

Mites were extracted from soil litter samples and bromeliads with Berlese-Tullgren funnels and preserved in $80 \%$ ethanol; previously, the bromeliad leaves were cut into small pieces. Then mites were observed under a stereoscopic microscope (Olympus SZ) and were cleared in potassium hydroxide (KOH) solution. Microscope slides were made using Hoyer's medium as a preserver for observation and illustration using a drawing tube adapted to a compound microscope (Nikon Optiphot-2). Additional observations were made with an optic microscope (Nikon Labophot-2). Line drawings were edited using the GNU Image Manipulation Program (GIMP) (The GIMP team 2014). Holotype and paratype specimens are deposited in the "Colección Nacional de Ácaros" (CNAC) kept at the "Instituto de Biología, Universidad Nacional Autónoma de México" in Mexico City, and three paratype specimens in the "Colección de Insectos de la Universidad de Morelos" (CIUM) at the "Centro de Investigación en Biodiversidad y Conservación, Universidad Autónoma del Estado de Morelos", in Cuernavaca, Morelos, Mexico.

The nomenclature for describing palp and leg chaetotaxy follows Grandjean $(1944,1946)$ and Fan \& Walter (2011), and the terminology of idiosomal chaetotaxy follows Kethley (1990) and Fan \& Walter (2011). In descriptions of male, protonymph and larva, only specific features that were found to be different from those of females are mentioned. All measurements are given in micrometres $(\mu \mathrm{m})$.

\title{
Results
}

\author{
Subclass Acari Sundevall, 1833 \\ Superorder Acariformes Zakhvatkin, 1952 \\ Order Trombidiformes Reuter, 1909 \\ Suborder Prostigmata Kramer, 1877 \\ Supercohort Eleutherengonides Oudemans, 1909 \\ Cohorte Raphignathina Kethley, 1982 \\ Superfamily Raphignathoidea Kramer, 1877 \\ Family Camerobiidae Southcott, 1957 \\ Genus Neophyllobius Berlese, 1886 \\ Neophyllobius cibyci sp. nov. \\ urn:lsid:zoobank.org:act:66ED492F-1C66-4CD7-8FF1-5340094F49A4
}

Figs 1-4; Table 2

\section{Diagnosis}

This species is unique due to a combination of following characters: female with dorsal setae reaching setae immediately behind, femur II with three setae ( $d, v^{\prime}$ and $\left.v^{\prime \prime}\right)$, femur III with two setae ( $d$ and $\left.v^{\prime}\right)$, setae $d$ on genua I-IV reaching tibiae, short setae (about $1 / 6$ of podomere length) on femur I, setae $l$ ' and $d$ on femur I nearly located horizontally at same level, dorsal setae $c l$ and $d l$ distinctly longer than distance between setae $c l-d 1$ and $d 1-e l$ respectively, idiosomal setae $d 1$ longest, and setae $d$ and $l$ ' on palpal femur heavily spinose.

\section{Etymology}

The specific name incorporates the acronym of the "Centro de Investigación en Biodiversidad y Conservación" (CIByC) at the "Universidad Autónoma del Estado de Morelos" in recognition of its work on biological conservation. 


\section{Type material}

\section{Holotype}

MEXICO: $\odot$, CNAC009229, ex Tillandsia hubertiana at 2.5 meters (m) on Quercus obtusata. Collected from the type locality on 12 Mar. 2014, O. Cortés and R. Paredes coll. (RPL1219).

\section{Paratypes}

MEXICO: 1 , CNAC009230, ex T. schiedeana at $3 \mathrm{~m}$ on Q. obtusata (RPL1220); 1 , CNAC009231, ex T. schiedeana at $3.05 \mathrm{~m}$ on Q. obtusata (RPL1223); 1 \%, CNAC009232, 1 L, CNAC009243, ex T. hubertiana at $2.1 \mathrm{~m}$ on Q. obtusata (RPL1225); 1 \%, CNAC009233, ex T. hubertiana at $2.7 \mathrm{~m}$ on Sapium macrocarpum (RPL1237); 1 \%, CNAC009234, ex T. schiedeana at $2.7 \mathrm{~m}$ on S. macrocarpum (RPL1238); 1 \%, CIUM, ex T. schiedeana at $2.7 \mathrm{~m}$ on S. macrocarpum (RPL1241); 1 +, CNAC009235, ex T. schiedeana at $2.9 \mathrm{~m}$ on Q. obtusata, 22 Aug. 2014, S. Gómez and R. Paredes coll. (RPL1295); 1 , CNAC009236, ex T. schiedeana at $2.6 \mathrm{~m}$ on S. macrocarpum, 22 Aug. 2014, S. Gómez and R. Paredes coll. (RPL1304); 1 +, CNAC009237, on soil litter of S. macrocarpum, 23 Oct. 2014, R. Reyes and R. Paredes coll. (RPL1341); 1 O, CNAC009238, ex T. hubertiana at $3.6 \mathrm{~m}$ on Q. obtusata (RPL1222); 1 o, CNAC009239, ex T. hubertiana at $2.7 \mathrm{~m}$ on S. macrocarpum, 30 Apr. 2014 (RPL1276); 1 , CNAC009240, ex T. schiedeana at $2.4 \mathrm{~m}$ on S. macrocarpum, 22 Aug. 2014, S. Gómez and R. Paredes coll. (RPL1301); 1 PN, CNAC009241, ex T. hubertiana at $3.4 \mathrm{~m}$ on Q. obtusata, 30 Apr. 2014 (RPL1255);

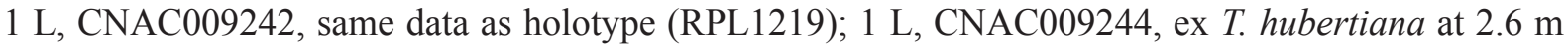
on S. macrocarpum, 30 Apr. 2014 (RPL1279). All collected from the type locality, with same data as holotype except where noted.

\section{Type locality}

MEXICO: Morelos, Tepoztlán, $1 \mathrm{~km} \mathrm{~S}$ of San Andrés de la Cal, $18.94305^{\circ} \mathrm{N}, 99.11786^{\circ} \mathrm{W}, 1490 \mathrm{~m}$ a.s.1.

\section{Description}

Female $(\mathrm{n}=10)($ Figs $1,3 \mathrm{~A}-\mathrm{D}, 4 \mathrm{~A}-\mathrm{D})$

Holotype female (followed in parentheses by range of holotype and nine paratype females).

Gnathosoma. 87 (81-98) long and 93 (77-93) wide. Subcapitulum with subcapitular setae $m 28$ (28-31) and two pairs of adoral setae Orl 11 (9-14) and Or2 9 (8-13); these three pairs are nude and slender, $m$ longest (Fig. 1B); distance $m-m 25$ (21-25). Chelicerae 38 (30-44) long. Palp, five-segmented with following setal distribution: trochanter without setae; femur with two serrate setae, $d 20(17-20)$ and $l$ ' 39 (31-39); genu with one long, slender, nude dorsal $(d)$ seta 39 (33-39); tibia with three tactile setae ( $l$ ', $l$ " and $d$ ) and one claw (sword-like seta); tarsus with two eupathidia ( $\mathrm{acm} \zeta$ and sul $)$ ), two simple setae ( $b a$ and $v a$ ) and one small solenidion ( $\omega$ ) (Fig. 1A). Setae elcp present.

Idiosoma. Longer than wide, 280 (270-350) long (gnathosoma excluded), 235 (195-320) wide. Cuticle striated, except on coxae and attenuated between setal pairs $c 1, d 1$, el and $f l$ (Fig. 1C). Dorsum. With 15 pairs of serrated setae set on small tubercles; all setae are long, $d 1$ longest and $h 2$ shortest; all setal pairs are longer than distance to setal pairs immediately behind. Two pairs of eyes are positioned between setae sci and sce. Length of setae: vi 58 (47-58), ve 50 (42-56), sci 46 (4053), sce 46 (42-52), $p d x 67$ (55-71), c1 80 (66-83), c2 70 (53-70), d1 82 (64-82), d2 52 (43-54), el 77 (60-77), e2 52 (45-57), fl 67 (54-72), f2 41 (36-43), h1 35 (34-39), h2 34 (29-34). Distances between setae: vi-vi 66 (45-66), ve-ve 96 (70-100), vi-ve 26 (26-32), sci-sci 115 (91-120), sce-sce 145 (125-150), sci-sce 45 (35-45), cl-dl 45 (34-58), dl-dl 16 (10-16), dl-d2 83 (82-94), d1-el 42 (39-46), ve-sci 22 (15-22), pdx-pdx 23 (13-24), pdx-c1 27 (22-37), c1-c1 16 (11-17), c1-c2 98 (86-100), c2-c2 185 (155-190), el-el 14 (11-16), el-f1 46 (37-59), fl-h1 50 (39-57), el-e2 

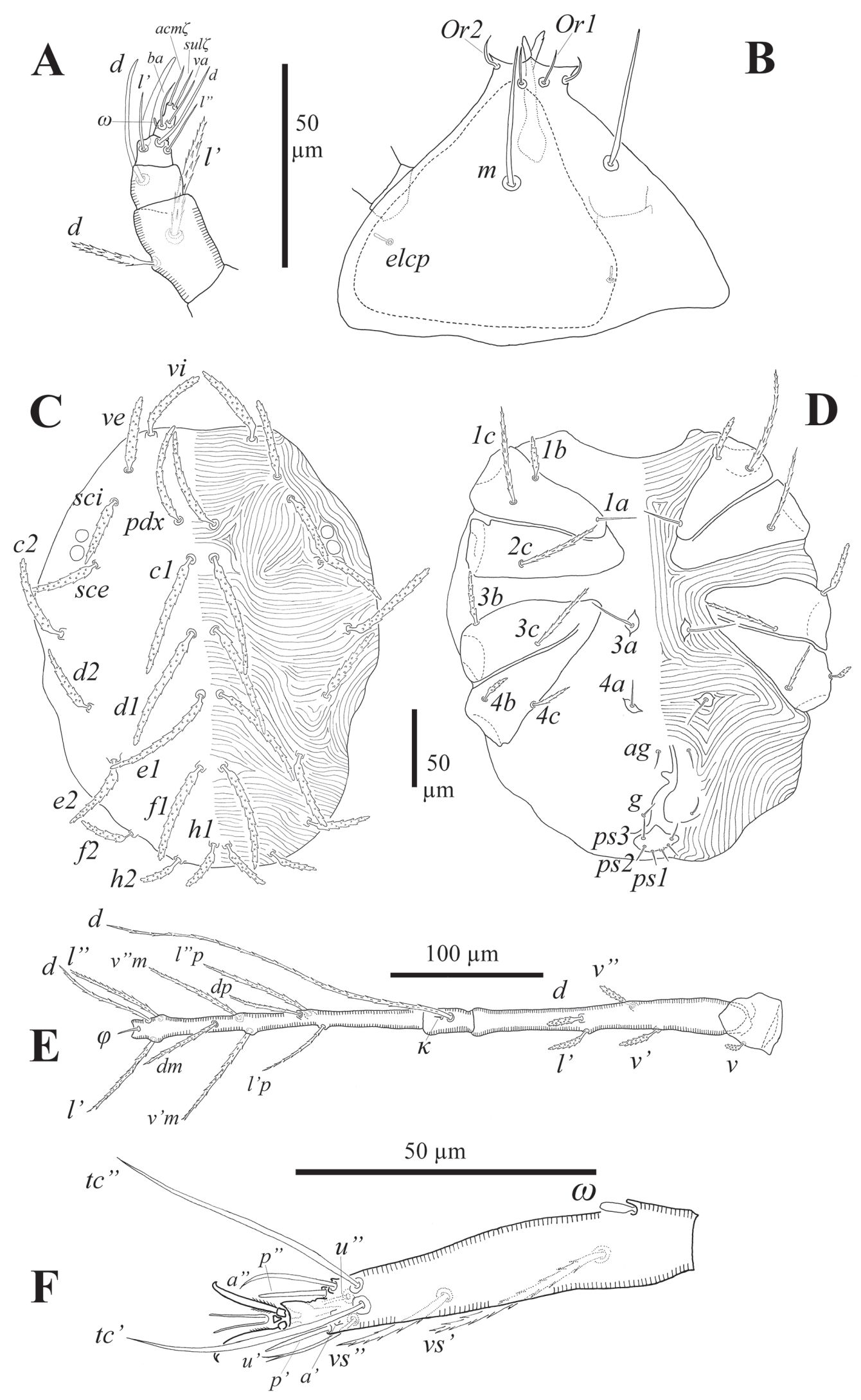

Fig. 1. Neophyllobius cibyci sp. nov., + , holotype. A. Palp. B. Subcapitulum. C. Dorsal idiosoma. D. Ventral idiosoma. E. Trochanter-tibia of leg I. F. Tarsus I. 


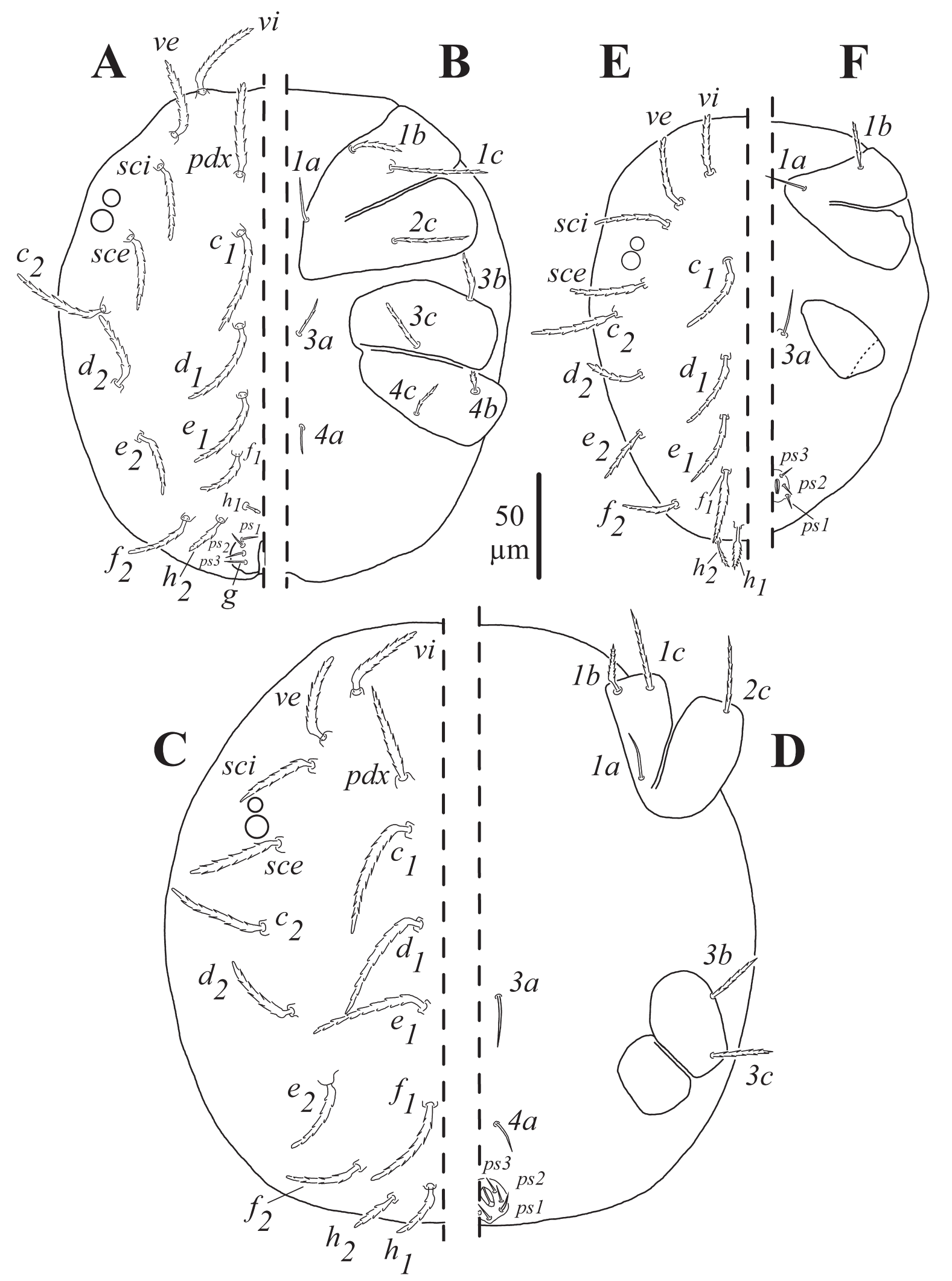

Fig. 2. Neophyllobius cibyci sp. nov. A-B. Ô, paratype (CNAC009238). A. Dorsal idiosoma. B. Ventral idiosoma. C-D. Protonymph, paratype (CNAC009241). C. Dorsal idiosoma. D. Ventral idiosoma. E-F. Larva, paratype (CNAC009242). E. Dorsal idiosoma. F. Ventral idiosoma. 
PAREDES-LEÓN R. et al., New species of camerobiid mites and setal homology in Neophyllobius

66 (56-70), d2-e2 42 (39-45), fl-f1 14 (9-14), fl-f2 66 (46-66), f2-f2 115 (105-125), e2-f2 42 (33-71), h1-h1 10 (6-11), h1-h2 30 (21-30), h2-h2 61 (50-68), f2-h2 33 (29-40). Venter. Coxal setae thinner than dorsal setae. Setal pairs $1 a, 3 a, 4 a, a g, g, p s 1, p s 2$ and $p s 3$ nude and short. Setae $1 b, 1 c, 2 c, 3 b, 3 c, 4 b$ and $4 c$ serrated. Setae $1 c$ longest and $p s 1-3$ shortest. Setal pairs $3 a$ and $4 a$ located on individual platelets. Genito-anal valves with one pair of genital setae $(g)$. Coxa I grouped with coxa II, and coxa III with IV but not completely fused (Fig. 1D). Length of setae: 1 a 26 (25-29), Ib 29 (22-30), 1c 69 (53-69), 2c 54 (33-56), $3 a 34$ (33-38), $3 b 37$ (25-40), 3c 49 (34-50), $4 a 18$ (18-26), $4 b 21$ (17-22), 4c 30 (22-31), ag 15 (15-19), g 10 (10-15), ps1 12 (10-14), ps2 12 (10-14), ps3 12 (9-12).

LEGs. Slender and long, leg I and IV longest. Lengths (excluding ambulacra): leg I 565 (480-565), leg II 495 (440-500), leg III 475 (465-530), leg IV 550 (510-590). Podomere lengths: femur I 180 (155-180), femur II 145 (125-145), femur III 145 (130-145), femur IV 165 (135-165), tibia I 185 (165-185), tibia II 160 (135-160), tibia III 185 (165-190), tibia IV 195 (180-200), tarsus I 62 (60-70), tarsus II 69 (60-70), tarsus III 71 (59-71), tarsus IV 71 (64-76). Leg setae as indicated in Figs 1E-F, 3A-D and $4 \mathrm{~A}-\mathrm{D}$. Tarsus I with five setal pairs: $v s$ serrated, $t c, a, p$ and $u$ slender and nude, $u$ bifurcated at tip. Setae tc longest (Fig. 1F). Setae lengths: $v$ ' on femur I 26 (21-27), $v$ "' on femur I 27 (20-30), l' on femur I $28(21-30), d$ on femur I 24 (19-24), dorsal seta on genu I 250 (210-265), dorsal seta on genu II 275 (210-280), dorsal seta on genu III 335 (230-340), dorsal seta on genu IV 360 (215-360), solenidion $\omega$ on tarsus I $6(6), \omega$ on tarsus II 5 (4-5). All tarsi with ambulacrum bearing a pair of claws and an empodium with two rows of tenent hairs. Counts of setae on legs I-IV, indicating additional solenidia in parenthesis: coxae: $3-1-2-2$, trochanters $1-1-1-1$, femora $4-3-2-2$, genua $1(\kappa)-1(\kappa)-1-1$, tibiae $9(\varphi)-8(\varphi)-8(\varphi)-7(\varphi)$, tarsi $10(\omega)-10(\omega)-8-8$.

Male (Figs 2A-B, 3E-H, 4E-H), range of three paratypes

Gnathosoma. 72-81 long and 65-72 wide. Subcapitular setae $m$ 25-26, setae $\operatorname{Or} 19$, Or2 8-9, distance $m-m$ 17-19. Chelicerae 20-24 long. Length of palpal setae: femur $d 18-20$ and $l^{\prime} 33-34$, and genu $d 35$.

IDIOSOMA. 195-210 long (gnathosoma excluded), 170-180 wide. Dorsum (Fig. 2A). Setae shorter than those of females, $c l$ longest and $h 1$ shortest. Length of setae: vi 35-38, ve 42, sci 38-42, sce 37-38, $p d x$ 42-44, c1 51-53, c2 47, d1 40, d2 40-41, el 45-46, e2 34-35, f1 24-25, f2 30, h1 9-10, h2 22. Distances between setae: vi-vi 40-45, ve-ve 65-69, vi-ve 20-25, sci-sci 80-87, sce-sce 105-112, sci-sce 10-11, cl-dl 39-44, dl-dl 8-10, d1-d2 55-59, dl-el 30-33, ve-sci 15-17, pdx-pdx 9-10, $p d x-c 1$ 25-31, c1-cl 9-10, c1-c2 65-75, c2-c2 124-133, el-el 8, el-fl 32-35, f1-h1 22-25, e1-e2 48-50, d2-e2 26-31,fl-fl 8,fl-f2 35-42, f2-f2 63-66, e2-f2 40-43, h1-h1 8, h1-h2 14-15, h2-h2 34-38, f2-h2 15-16. Venter (Fig. 2B). Agenital setae (ag) absent. Genital seta ( $g$ ) very close to $p s 3$. Length of setae: $1 a$ 16-18, $1 b$ 20-23, $1 c$ 44-47, 2c 35-37, 3a 17-18, 3b 22-24, 3c 25, 4a 12-13, 4b 12-13, 4c 16-21, ps1 9, ps2 9, ps3 9, g 10.

Legs. Leg IV longest. Lengths (excluding ambulacra): leg I 465-475, leg II 405-410, leg III 440-450, leg IV 475-485. Podomere lengths: femur I 150-155, femur II 115-125, femur III 120, femur IV 130135, tibia I 155, tibia II 125-130, tibia III 155-160, tibia IV 155-160, tarsus I 58-60, tarsus II 58-60, tarsus III 60, tarsus IV 65. Tibia I with two solenidia ( $\varphi$ and $\varphi 2$ ), and all tarsi with one long basal solenidion $(\omega)$ (Fig. 4E-H). Leg setae as indicated in Fig. 3E-H and 4E-H. Setae lengths: $v$ ' on femur I $21-22, v$ " on femur I 25-27, l' on femur I $22, d$ on femur I 24-25, dorsal seta on genu I 110-125, dorsal seta on genu II 130, dorsal seta on genu III 185-195, dorsal seta on genu IV 215-230, solenidion $\omega$ on tarsus I $27-28, \omega$ on tarsus II $30, \omega$ on tarsus III $30, \omega$ on tarsus IV $27-28$. Counts of setae on legs I-IV, indicating additional solenidia in parenthesis: coxae: $3-1-2-2$, trochanters 1-1-1-1, femora 4-3-2-2, genua $1(\kappa)-1(\kappa)-1-1$, tibiae $9(\varphi, \varphi 2)-8(\varphi)-8(\varphi)-7(\varphi)$, tarsi $10(\omega)-10(\omega)-8(\omega)-8(\omega)$. 
Protonymph (Figs 2C-D, 3I-L, 4I-L)

Gnathosoma. 70 long and 65 wide. Subcapitular setae $m$ 20, setae $\operatorname{Or} 1$ 5, Or2 6, distance $m-m 14$. Chelicerae 24 long. Length of palpal setae: femur $d 13$ and $l$ '28, and genu $d 27$.

IDIosoma. 295 long (gnathosoma excluded), 230 wide. Dorsum (Fig. 2C). Setae shorter than those of females, $c 1$ longest. Length of setae: vi 41, ve 40, sci 38, sce 43, pdx 46, c1 60, c2 46, d1 56, d2 39, e1 56, e2 40,f1 50, f2 35, h1 30, h2 22. Distances between setae: vi-vi 48, ve-ve 83, vi-ve 18, sci-sci 97 , sce-sce 130, sci-sce 39, cl-dl 42, d1-d1 11, dl-d2 69, dl-el 38, ve-sci 14, pdx-pdx 17, pdx-cl 26, $c 1-c 1$ 10, cl-c2 78, c2-c2 150, el-e1 11, el-fl 45,f1-h1 38, el-e2 54, d2-e2 36,f1-f1 11,f1-f2 44, $f 2-f 2$ 86, e2-f2 42, h1-h1 5, h1-h2 18, h2-h2 35, f2-h2 23. Venter (Fig. 2D). Setal pairs $4 b, 4 c, a g$ and $g$ absent. Length of setae: $1 a 21,1 b 23,1 c 35,2 c 34,3 a 26,3 b 27,3 c 11,4 a 14$, ps 1 9, ps 2 9, ps 39 .

LEGS. Leg I longest. Lengths (excluding ambulacra): leg I 375, leg II 340, leg III 315, leg IV 325. Podomere lengths: femur I 130, femur II 95, femur III 100, femur IV 100, tibia I 115, tibia II 95, tibia III 115, tibia IV 105, tarsus I 55, tarsus II 55, tarsus III 55, tarsus IV 55. Leg setae as shown in Figs 3I-L and 4I-L. Setae lengths: $v$ " on femur I 21, $l$ ' on femur I $20, d$ on femur I 18, dorsal seta on genu I 185, dorsal seta on genu II 205, dorsal seta on genu III 240, dorsal seta on genu IV 210 , solenidion $\omega$ on tarsus I 5, $\omega$ on tarsus II 4. Counts of setae on legs I-IV, indicating additional solenidia in parenthesis: coxae:
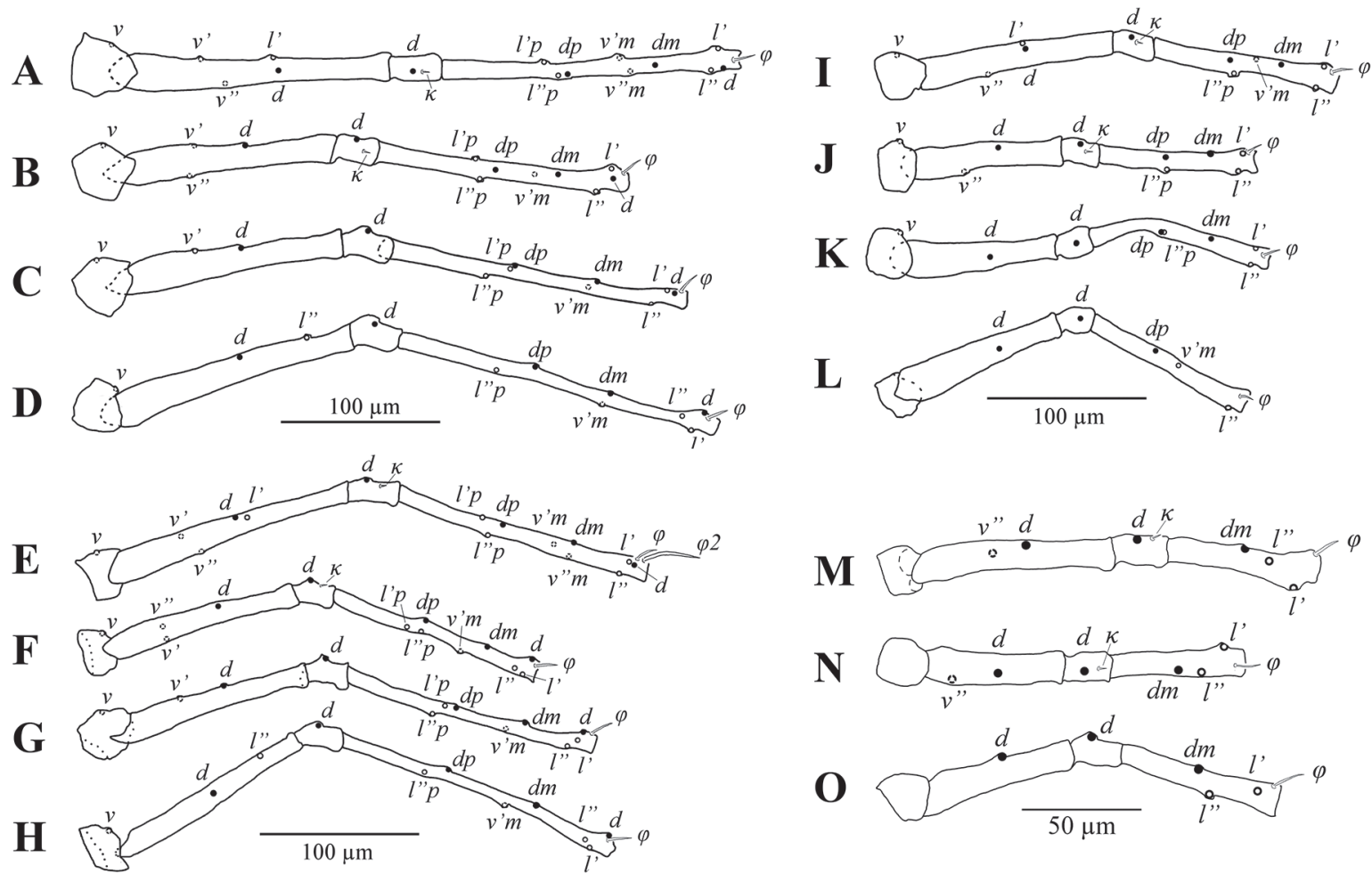

Fig. 3. Schematic leg setations of Neophyllobius cibyci sp. nov. A-D. + , holotype. A. Trochanter-tibia of leg I. B. Trochanter-tibia of leg II. C. Trochanter-tibia of leg III. D. Trochanter-tibia of leg IV. E-H. $\widehat{\text { o, }}$ paratype (CNAC009238). E. Trochanter-tibia of leg I. F. Trochanter-tibia of leg II. G. Trochanter-tibia of leg III. H.Trochanter-tibia of leg IV. I-L. Protonymph, paratype (CNAC009241). I. Trochantertibia of leg I. J. Trochanter-tibia of leg II. K. Trochanter-tibia of leg III. L. Trochanter-tibia of leg IV. M-O. Larva, paratype (CNAC009242). M. Trochanter-tibia of leg I. N. Trochanter-tibia of leg II. O. Trochanter-tibia of leg III. 
PAREDES-LEÓN R. et al., New species of camerobiid mites and setal homology in Neophyllobius

3-1-2-0, trochanters $1-1-1-0$, femora $3-2-1-1$, genua $1(\kappa)-1(\kappa)-1-1$, tibiae $6(\varphi)-5(\varphi)-5(\varphi)-3(\varphi)$, tarsi $9(\omega)-9(\omega)-7-5$.

Larva (Figs 2E-F, 3M-O, 4M-O), range of three paratypes

Gnathosoma. 45-50 long and 60 wide. Subcapitular setae $m$ and palpal femur seta $d$ absent, setae Or 1 88, Or 2 8. Chelicerae 20-22 long. Length of palpal setae: femur l'20-21 and genu $d 20$.

Idiosoma. 165-180 long (gnathosoma excluded), 130-135 wide. Dorsum (Fig. 2E). Setae shorter than those of females, $c 2$ longest. Setal pair $p d x$ absent. Length of setae: vi 28-29, ve 30-34, sci 34, sce 34, c1 35-38, c2 42-43, d1 32-34, d2 28, el 35-36, e2 25-27, f1 30-34, f2 23-24, h1 17-18, h2 15. Distances between setae: vi-vi 30-35, ve-ve 58-60, vi-ve 18-20, sci-sci 65-68, sce-sce 85, sci-sce 28-29, c1-d1 43-46, d1-d1 10, d1-d2 37-38, d1-el 25-27, ve-sci 10-11, vi-cl 35-41, c1-c1 10, c1-c2 55-60, c2c2 105-110, el-el 10, el-f1 25-30,fl-h1 22-24, el-e2 35-39, d2-e2 37-40,f1-fl 9-10,fl-f2 25-26, $f 2-f 2$ 50-55, e2-f2 30-32, h1-h1 8, h1-h2 9, h2-h2 20-22, f2-h2 22-24. Venter (Fig. 2F). Setal pairs $1 c, 2 c, 3 b, 3 c, 4 b, 4 c, a g$ and $g$ absent. Length of setae: $1 a$ 20-24, $1 b 22-23,3 a 25$, ps 17 , ps 27 , ps 38.

LEGs. Leg I longest. Lengths (excluding ambulacra): leg I 260-265, leg II 240, leg III 250-255. Podomere lengths: femur I 80, femur II 60, femur III 70-75, tibia I 60-65, tibia II 55, tibia III 65-70, tarsus I 45, tarsus II 45, tarsus III 45. Leg setae as indicated in Figs 3M-O and 4M-O. Setae lengths: $v$ " on femur I $32-34, d$ on femur I 22 , dorsal seta on genu I $43-45$, dorsal seta on genu II 33 , dorsal seta on genu III 45 , solenidion $\omega$ on tarsus I 3, $\omega$ on tarsus II 3. Counts of setae on legs I-III, indicating additional solenidia in parenthesis: coxae: $2-0-0$, trochanters $0-0-0$, femora $2-2-1$, genua $1(\kappa)-1(\kappa)-1$, tibiae $3(\varphi)-3(\varphi)-3(\varphi)$, $\operatorname{tarsi} 7(\omega)-7(\omega)-5$.

\section{Intraspecific variation}

In the case of Neophyllobius cibyci sp. nov., we observed that leg setation teratologies are relatively rare, but include the following: 1) adult specimens with certain setae in different locations; for example, female right femur I with $v$ " distal to $d$ instead of proximal (CNAC009236), female right femur I with $l$ ' positioned before $d$ (CNAC009234), female left femur I with l' positioned before $d$ (CNAC009233), female tibiae I with seta $d m$ between $v^{\prime}$ and $v$ " (CNAC009231 and CNAC009235) instead of distal, female right tibia I with $d m$ between $v^{\prime}$ and $v$ " (CNAC009232) instead of distal, and male right tibia I with l'p distal to $l$ " $p$ instead of proximal (CNAC009238); 2) female specimens without setae on left or right legs, for example left femur I without $l$ ' (CIUM), left femur I without $v$ " (CNAC009236), and left tibia I without $v "$ (CNAC009236 and CIUM).

\section{Remarks}

Neophyllobius cibyci sp. nov. resembles N. farrieri De Leon, 1958 collected on "Spanish moss" (probably Tillandsia usneoides) in Oaxaca, Mexico. In both species, dorsal setae on genua I-IV are very long, extending beyond the tip of the tarsus, setae on femur I are short (about $1 / 6$ of podomere length), and setae $l$ ' and $d$ on femur I are nearly located at the same level. These species can be differentiated by the following characters: in $N$. cibyci sp. nov., dorsal setae $c l$ and $d l$ are distinctly longer than the distance between setae $c 1-d 1$ and $d 1-e 1$ respectively, setae $d 1$ are the longest of the dorsal setae, and setae $d$ and $l$ ' on palpal femur are heavily spinose. In $N$. farrieri, the lengths of dorsal setae $c l$ and $d l$ are the same as the distance between setae $c l-d l$ and $d 1-e l$ respectively; setae $e l$ are the longest of the dorsal setae, and setae $d$ and $l$ ' on palpal femur are weakly spinose.

Neophyllobius cibyci sp. nov. includes at least three postembryonic instars (larva, protonymph and adult). We found only one nymphal instar (protonymph) which resembles the female type proposed by Bolland (2001). 

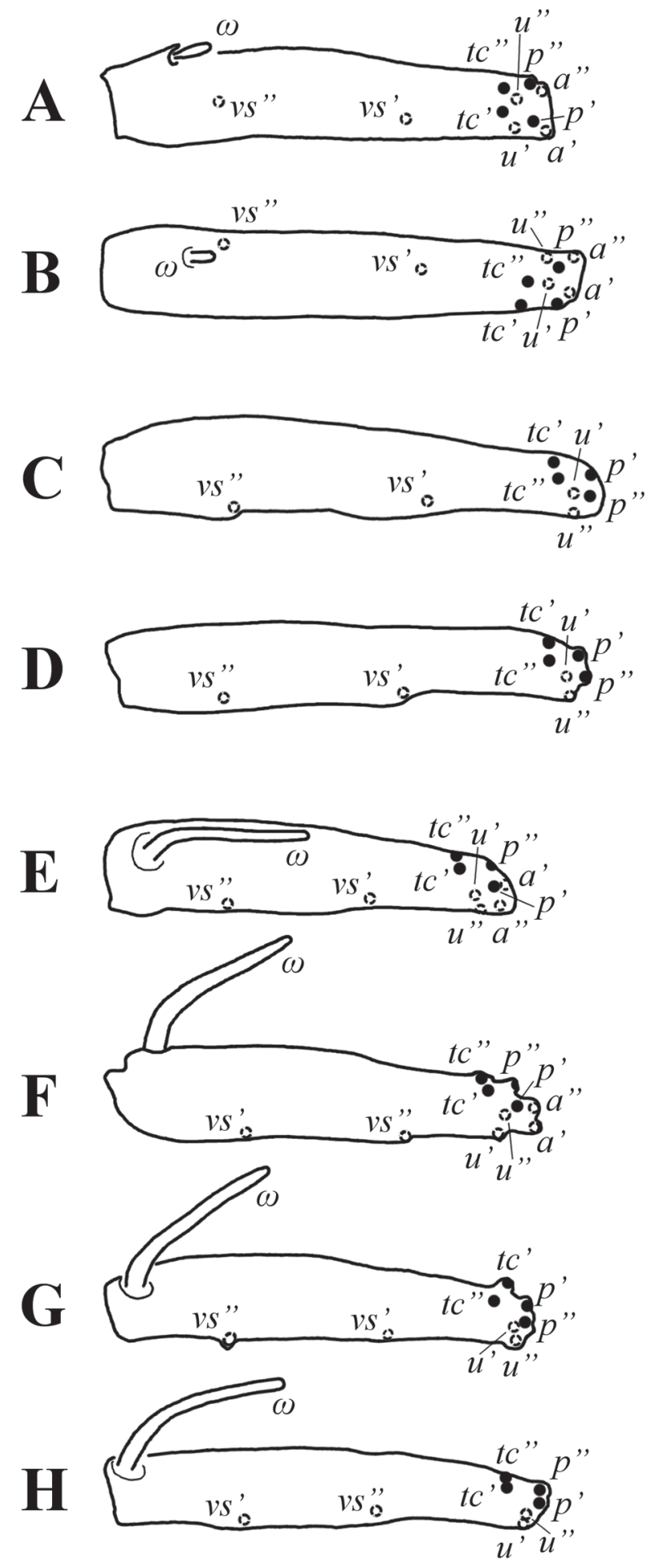
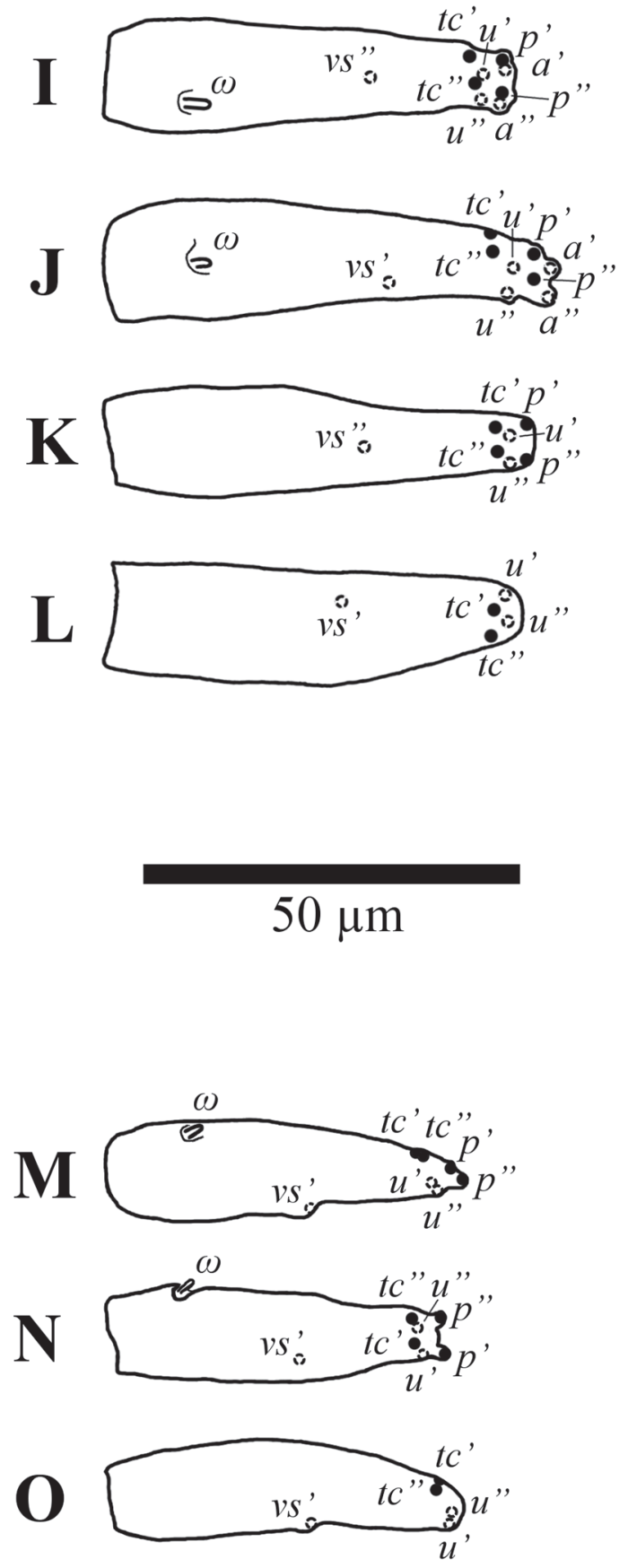

Fig. 4. Schematic tarsal setations of Neophyllobius cibyci sp. nov. A-D. $q$, holotype. A. Tarsus I. B. Tarsus II. C. Tarsus III. D. Tarsus IV. E-H. $\widehat{\jmath}$, paratype (CNAC009238). E. Tarsus I. F. Tarsus II. G. Tarsus III. H. Tarsus IV. I-L. Protonymph, paratype (CNAC009241). I. Tarsus I. J. Tarsus II. K. Tarsus III. L. Tarsus IV. M-O. Larva, paratype (CNAC009242). M. Tarsus I. N. Tarsus II. O. Tarsus III. 
PAREDES-LEÓN R. et al., New species of camerobiid mites and setal homology in Neophyllobius

\section{Ecology}

Neophyllobius cibyci sp. nov. was the most abundant camerobiid species with 17 specimens, most of which (76.5\%) were collected in dry season (March and April). This species is deemed to be an inhabitant of the tree canopy because most specimens (94\%) were collected on epiphytic bromeliads at $2.8 \mathrm{~m}( \pm 0.4)$ and only one female specimen (CNAC009237) was found on soil litter. Neophyllobius cibyci sp. nov. was found in low numbers, usually one specimen per sample, except for two samples which had two specimens each. The closely resembling species, $N$. farrieri, also inhabits epiphytic bromeliads of the genus Tillandsia.

\section{Distribution}

This species is only known from San Andrés de la Cal, Morelos, Mexico. The type locality of N. cibyci sp. nov. is about $440 \mathrm{~km}$ as the crow flies from the known distribution of $N$. farrieri (Puenta [sic.] de Nejapa, Oaxaca, Mexico).

\section{Setal homology among Neophyllobius cibyci sp. nov. instars}

The collection of different instars provides material for study and suggests the ontogenetic development pattern of gnathosoma, idiosoma and leg chaetotaxy. Although, Grandjean's idiosomal and leg chaetotaxy systems were previously applied to camerobiid mites (Kethley 1990; Fan \& Walter 2011), this is the first study of complete chaetotaxy (on gnathosoma, idiosoma and legs) involving three different instars (larva, protonymph and adult) of a camerobiid mite species. Swift's (2001) study of leg chaetotaxy of Caligonellidae (Raphignathina: Raphignathoidea), included one larva and one adult female of an undetermined species of Neophyllobius. We found only one nymphal instar (protonymph); for this reason and because the presence of deutonymph is questionable in Neophyllobius, we prefer not to hypothesise the presence of setae in this particular instar (deutonymph).

There are different concepts about the leg chaetotaxy. Fundamental setae are those present when the appendages in question are first formed, that is on legs I-III in the larva or on leg IV in the protonymph. Accessory setae are any which are formed during subsequent moults (Grandjean 1941; Norton 1977; Swift 2001). Setal priority for each podomere refers to a list of setal organs that appear at the beginning of ontogeny (fundamental setae) and have greater priority, or force, than organs than develop later (accessory setae), which suggests that these setal organs are less susceptible to evolutionary regression (Norton 1977; Swift 2001). Setae of equal priority are listed together within parentheses as proposed by Norton (1977).

Gnathosoma. Larvae have $\operatorname{Orl}$ and $\operatorname{Or} 2$. Setal pattern on palps is consistent across larva, protonymph and adults, except that dorsal seta $(d)$ on femur do not appear until the protonymphal instar; count of setae from palp coxa to tarsus: 1 (elcp), 0,2,1,3+1 claw, $4+\omega$. Setal pair $m$ on subcapitulum do not appear until the protonymphal instar.

IDIOsoma. The dorsal chaetotaxy in larvae includes 14 setal pairs: vi, ve, sci, sce, $c 1, c 2, d 1, d 2, e 1, e 2$, $f 1, f 2, h 1$ and $h 2$ (Fig. 2E). Setal pair $p d x$ appears in protonymph (Fig. 2C). The ventral chaetotaxy in larvae includes six setal pairs: $1 a, 1 b, 3 a, p s 1, p s 2$ and $p s 3$ (Fig. 2F). Setal pairs $1 c, 2 c, 3 b, 3 c$ and $4 a$ are added in protonymph (Fig. 2D). Setal pairs $4 b$ and $4 c$ are added in adults (Figs 1D, 2B). Setal pair $a g$ is present only in adult females (Fig. 1D).

Legs (Table 2). Setae $v$ are absent on trochanters I-III in larva (Fig. 3M-O), and do not appear until the protonymphal instar (Fig. 3I-K). Seta $v$ on trochanter IV does not appear until adulthood (Fig. 3D, H). Femora I-II of the larva with setae $v$ " and $d$ (Fig. 3M-N), femur III of the larva (Fig. 3O) and femur IV of the protonymph (Fig. 3L) only with seta $d$. Seta $l$ ' is added on femur I of the protonymph (Fig. 3I). Setae $v^{\prime}$ on femora I-III (Fig. 3A-C, E-G), and $l$ '” on femur IV (Fig. 3D, H) are added in adults. The setal 
Table 2. Setal leg ontogeny of Neophyllobius cibyci sp. nov., parentheses represent a setal pair and square brackets indicate additional setae in $\widehat{\partial}$.

\begin{tabular}{|c|c|c|c|c|c|c|}
\hline LEG & INSTAR & TROCHANTER & FEMUR & GENU & TIBIA & TARSUS \\
\hline \multirow{3}{*}{ I } & Larva & 0 & $d, v^{\prime \prime}$ & $d, \kappa$ & $d m,(l), \varphi$ & $v s^{\prime},(t c),(p),(u), \omega$ \\
\hline & Protonymph & $v$ & $d, v^{\prime \prime}, l^{\prime}$ & $d, \kappa$ & $d m,(l), \varphi, d p, l " p, v^{\prime} m$ & $v s^{\prime \prime},(t c),(p),(u),(a), \omega$ \\
\hline & Adult & $v$ & $d,(v), l^{\prime}$ & $d, \kappa$ & $d,(l),(v m), d p,(l p), d m, \varphi,[\varphi 2]$ & $(v s),(t c),(p),(u),(a), \omega$ \\
\hline \multirow{3}{*}{ II } & Larva & 0 & $d, v^{\prime \prime}$ & $d, \kappa$ & $d m,(l), \varphi$ & $v s^{\prime},(t c),(p),(u), \omega$ \\
\hline & Protonymph & $v$ & $d, v^{\prime \prime}$ & $d, \kappa$ & $d m,(l), \varphi, d p, l " p$ & $v s^{\prime},(t c),(p),(u),(a), \omega$ \\
\hline & Adult & $v$ & $d,(v)$ & $d, \kappa$ & $d,(l), v^{\prime} m, d p,(l p), d m, \varphi$ & $(v s),(t c),(p),(u),(a), \omega$ \\
\hline \multirow{3}{*}{ III } & Larva & 0 & $d$ & $d$ & $d m,(l), \varphi$ & $v s^{\prime},(t c),(u)$ \\
\hline & Protonymph & $v$ & $d$ & $d$ & $d m,(l), \varphi, d p, l " p$ & $v s^{\prime \prime},(t c),(p),(u)$ \\
\hline & Adult & $v$ & $d, v^{\prime}$ & $d$ & $d m,(l), \varphi,(l p), d p, d, v^{\prime} m$ & $(v s),(t c),(p),(u),[\omega]$ \\
\hline \multirow{2}{*}{ IV } & Protonymph & 0 & $d$ & $d$ & $d p, v^{\prime} m, l,, \varphi$ & $v s^{\prime},(t c),(u)$ \\
\hline & Adult & $v$ & $d, l$, & $d$ & $d p, v^{\prime} m,(l), \varphi, d, l " p, d m$ & $(v s),(t c),(p),(u),[\omega]$ \\
\hline
\end{tabular}

priorities on femora I and II for Neophyllobius cibyci sp. nov. are: $\left(d, v^{\prime \prime}\right), l^{\prime}, v^{\prime}$. Priorities on femora III and IV are: $d, l$ ', $v$ '. Genua I-II in all instars with seta $d$ and $\kappa$ (Fig. 3A-B, E-F, I-J, M-N), and genu III only with $d$ (Fig. 3C, G, K, O). Genu IV of the protonymph and adults only with seta $d$ (Fig. 3D, H, L).

Tibiae I-III of larva with setae $d m, l, l^{\prime \prime}$ and $\varphi$ (Fig. 3M-O). Tibia IV of the protonymph with setae $d p$, $v^{\prime} m, l$ " and $\varphi$ (Fig. 3L); $d p$ and $l " p$ are added to tibiae I-III (Fig. 3I-K) of the protonymph. Seta v'm is added to tibia I (Fig. 3I) of the protonymph. Setae $l^{\prime} p$, and $d$ are added to tibiae I-II of adults (Fig. 3A-B, E-F). Seta $v^{\prime \prime} m$ appears only on tibiae I of adults (Fig. 3A, E). Setae $l^{\prime} p$ and $v^{\prime} m$ are added to tibia III of adults (Fig. 3C, G). Setae $l$ ', $d p, l " p$ and $d$ are added to tibia IV of adults (Fig. 3D, H). Tibia I of males with $\varphi 2$ (Fig. 3E). The setal priorities for tibiae I and II in Neophyllobius cibyci sp. nov., are: (dm, l', l'), $\left(d p, l " p, v^{\prime} m\right),\left(d, l{ }^{\prime} p, v^{\prime \prime} m\right)$. Priorities on tibiae III and IV are similar except $v^{\prime \prime} m$ is not formed.

Tarsi I-II of the larva with $v s^{\prime},(t c),(p),(u)$ and $\omega$ (Fig. 4M-N), tarsus III with $v s^{\prime},(t c),(u)$ and $\omega$ (Fig. 4O). In tarsi I-II of protonymph, setal pair $a$ is added (Fig. 4I-J). Seta $v s^{\prime}$ is lost on tarsi I and III of protonymph but $v s^{\prime}$ " appears (Fig. 4I, K). Tarsus IV of the protonymph with $v s^{\prime},(t c)$ and (u) (Fig. 4L). Setae $v s^{\prime}$ reappears in tarsi I and III of adults (Fig. 4A, C, E, G). Seta $v s$ " appears on tarsi II and IV (Fig. 4B, D, F, H). Setal pair $p$ is added in tarsus IV of the adults (Fig. 4D, H). Tarsi III-IV of males with $\omega$ (Fig. 4G-H). The setal priorities for tarsi I and II are: (tc', $\left.t c^{\prime \prime}, u^{\prime}, u^{\prime \prime}, v s^{\prime}, p^{\prime}, p^{\prime \prime}\right),\left(a^{\prime}, a^{\prime \prime}, v s^{\prime \prime}\right)$. Priorities on tarsi III and IV are: ( $\left.t c^{\prime}, t c^{\prime \prime}, u^{\prime}, u^{\prime \prime}, v s^{\prime}\right),\left(p^{\prime}, p^{\prime \prime}, v s^{\prime}\right)$.

Neophyllobius tepoztlanensis sp. nov. urn:1sid:zoobank.org:act:A8A8CE4B-824C-40D7-A435-45A8E4401A4D

Fig. 5A-F

\section{Diagnosis}

This species is characterized as follows: dorsal setae reaching setae immediately behind, seta $d$ on femur I positioned in front of $l^{\prime}$, femur II with three setae ( $d, v^{\prime}$ and $\left.v^{\prime \prime}\right)$, femur III with two setae ( $d$ and $\left.v^{\prime}\right)$, setae $d$ on genua I-IV slightly less than half as long as tibiae I-IV respectively, dorsal seta $d 1$ less than half as long as width of body; dorsal setae $c l$ as long as setae $d 1$, setae $v$ " on femora I-II positioned distinctly in front of $v$ '. 
PAREDES-LEÓN R. et al., New species of camerobiid mites and setal homology in Neophyllobius

\section{Etymology}

The specific name makes reference to the municipality Tepoztlán, where the type locality is situated. The name of the municipality derives from two words in the náhuatl language, "Tepoztecatl" (a nahua divinity) and "tlan" (beside), so its meaning is "in the company of Tepoztécatl".

\section{Type material}

\section{Holotype}

MEXICO: + , CNAC009245, ex Tillandsia schiedeana at $2.4 \mathrm{~m}$ on Sapium macrocarpum. Collected from the type locality on 12 Mar. 2014, O. Cortés and R. Paredes coll. (RPL1232).

\section{Paratypes}

MEXICO: 1 q, CIUM, ex T. hubertiana at $3.2 \mathrm{~m}$ on S. macrocarpum, 30 Apr. 2014 (RPL1267); 1 q, CNAC009246, ex T. hubertiana at $2.6 \mathrm{~m}$ on S. macrocarpum, 22 Aug. 2014, S. Gómez and R. Paredes coll. (RPL1303). Both specimens collected from the type locality, with same data as holotype except where noted.

\section{Type locality}

MEXICO: Morelos, Tepoztlán, 1 km S of San Andrés de la Cal, $18.94408^{\circ}$ N, 99.11924ํW, 1478 m a.s.l.

\section{Description}

Female $(\mathrm{n}=3)$ (Fig. 5A-F)

Holotype female (followed in parentheses by range of holotype and two paratype females).

Gnathosoma. 68 (68-79) long and 77 (71-82) wide. Subcapitulum with subcapitular setae $m 20$ (20-24) and two pairs of adoral setae $\operatorname{Orl} 9$ (9) and $\operatorname{Or} 210$ (8-10); these three pairs nude and slender, $m$ longest (Fig. 5B); distance $m-m 20$ (20-21). Chelicerae 40 (27-40) long. Palp, five-segmented with following setal distribution: trochanter without setae; femur with two serrated setae, $d 19$ (17-19) and l' 31 (27$31)$; genu with one long, slender, nude dorsal $(d)$ seta 31 (30-32); tibia with three tactile setae (l', $l$ '" and $d$ ) and one claw (sword-like seta); tarsus with two eupathidia ( $a \mathrm{~cm} \zeta$ and $s u l \zeta$ ), two simple setae ( $b a$ and $v a$ ) and one small solenidion ( $\omega$ ) (Fig. 5A). Setae elcp present.

IDIosoma. Longer than wide, 285 (225-285) long (gnathosoma excluded), 230 (200-235) wide. Cuticle striated, except on coxae and attenuated between setal pair el (Fig. 5C-D). Dorsum. With 15 pairs of serrated setae set on small tubercles; each setal pair just reaching next setal pairs (in transversal row), $c 2$ longest and $h 2$ shortest. Two pairs of eyes are positioned between setae sci and sce. Length of setae: vi 48 (48-53), ve 46 (46-48), sci 43 (43-50), sce 46 (46-48), pdx 46 (46-53), c1 50 (50-54), c2 63 (53-63), d1 51 (50-56), d2 40 (40-44), el 53 (53-56), e2 46 (40-46), f1 50 (50-54), f2 30 (30-32), hl 34 (32-34), h2 28 (27-28). Distances between setae: vi-vi 40 (40-50), ve-ve 82 (64-94), vi-ve 28 (24-30), sci-sci 98 (80-110), sce-sce 130 (115-140), sci-sce 40 (34-40), cl-d1 46 (42-52), d1-d1 15 (14-15), d1-d2 70 (62-78), d1-el 40 (38-43), ve-sci 19 (19-21), pdx-pdx 12 (11-12), pdx-c1 31 (29-31), c1-cl 15 (14-15), c1-c2 77 (70-86), c2-c2 160 (140-170), el-el 12 (10-12), el-fl 42 (3442), f1-h1 56 (38-56), e1-e2 54 (52-62), d2-e2 34 (34-37), f1-f1 11 (9-12), f1-f2 53 (43-53), f2-f2 91 (83-94), e2-f2 50 (30-50), h1-h1 8 (8-11), h1-h2 25 (23-25), h2-h2 57 (54-57), f2-h2 42 (26-42). Venter. Coxal setae slenderer than dorsal setae. Setal pairs $1 a, 3 a, 4 a, a g, g, p s 1, p s 2$ and ps 3 nude and short. Setae $1 b, 1 c, 2 c, 3 b, 3 c, 4 b$ and $4 c$ serrated. Setae $1 c$ longest and $g$ shortest. Setal pairs $4 a$ and $a g$ located on individual platelets. Genito-anal valves with one pair of genital setae $(g)$. Coxa I grouped with coxa II, and coxa III with IV but not completely fused (Fig. 5D). Length of setae: $1 a 32$ (27-32), $1 b$ 22 (21-22), 1c 50 (42-50), 2c 42 (35-42), $3 a 37$ (34-37), $3 b 30$ (25-30), 3c 31 (30-31), 4a 19 (19-30), $4 b 18$ (14-18), 4c 20 (19-20), ag 16 (12-16), g 9 (9-12), ps 14 (9-15), ps2 11 (10-12), ps3 12 (10-14). 

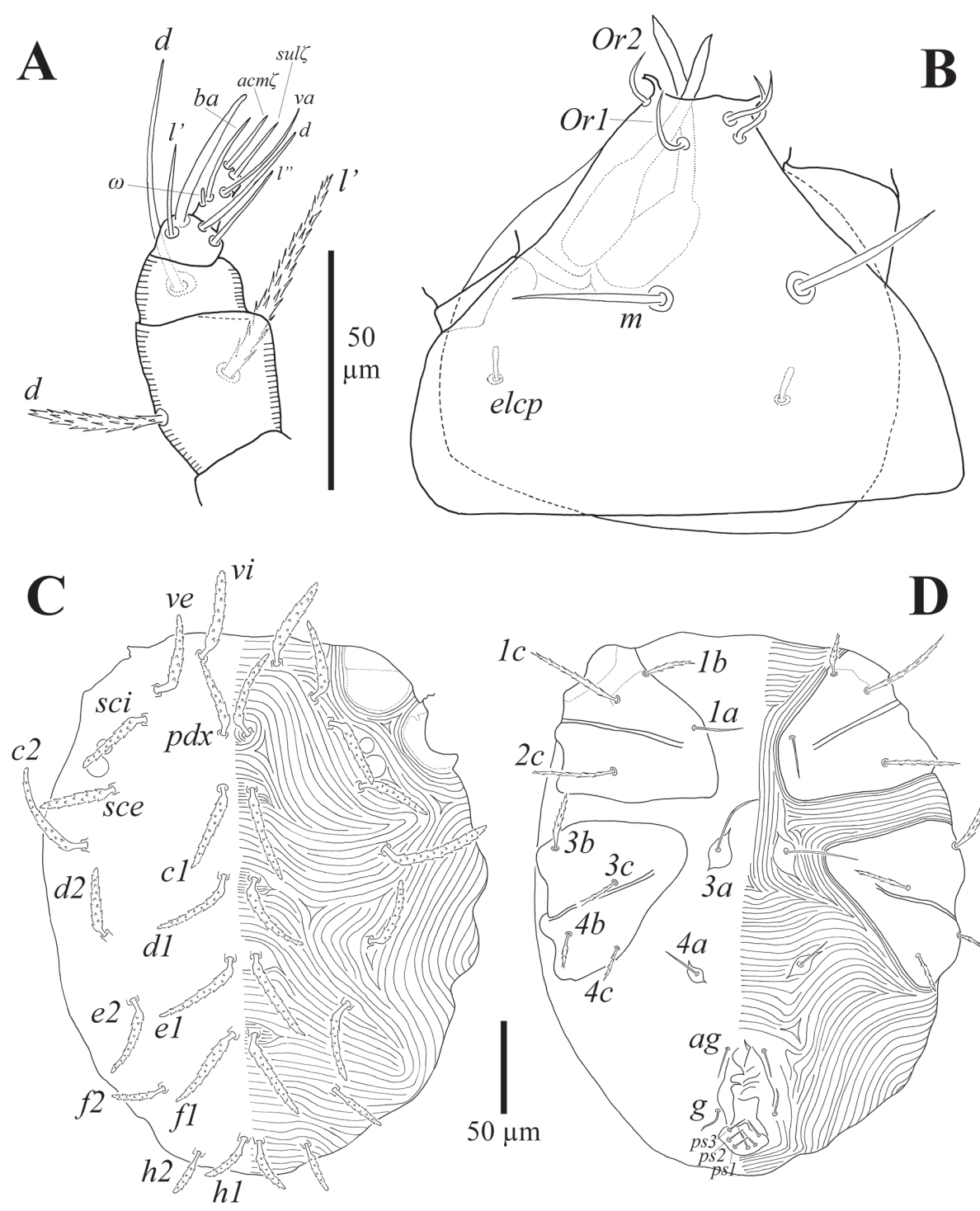

D
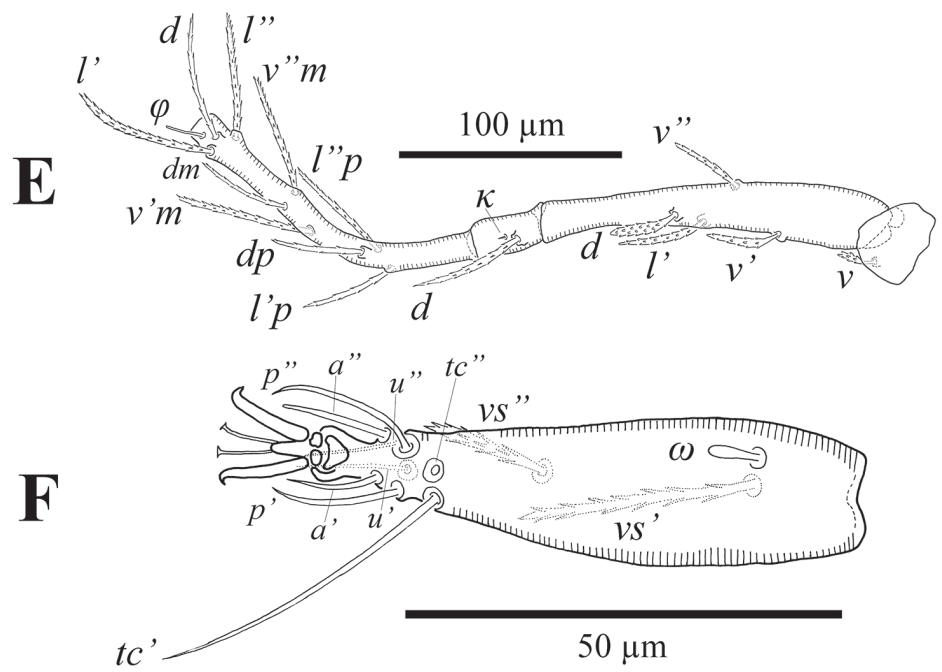

Fig. 5. Neophyllobius tepoztlanensis sp. nov.,, , holotype. A. Palp. B. Subcapitulum. C. Dorsal idiosoma. D. Ventral idiosoma. E. Trochanter-tibia of leg I. F. Tarsus I. 
PAREDES-LEÓN R. et al., New species of camerobiid mites and setal homology in Neophyllobius

LEGS. Slender and long, leg IV longest. Lengths (excluding ambulacra): leg I 500 (420-510), leg II 415 (390-450), leg III 455 (417-485), leg IV 505 (470-530). Podomere lengths: femur I 160 (160-165), femur II 120 (110-130), femur III 125 (115-135), femur IV 140 (130-155), tibia I 145 (135-160), tibia II 115 (110-125), tibia III 130 (130-165), tibia IV 165 (155-175), tarsus I 59 (54-61), tarsus II 58 (56-61), tarsus III 60 (57-66), tarsus IV 66 (62-66). Leg setae as indicated in Fig. 5E-F. Tarsus I with five setal pairs: $v s$ serrated, $t c, a, p$ and $u$ slender and nude, $u$ bifurcated at tip. Setae $t c$ longest. Setae lengths: $v$ ' on femur I 34 (30-34), $v$ "' on femur I 34 (30-37), $l$ ' on femur I 38 (31-38), $d$ on femur I 31 (30-31), dorsal seta on genu I 54 (48-54), dorsal seta on genu II 45 (39-45), dorsal seta on genu III 45 (42-47), dorsal seta on genu IV 71 (68-71). All tarsi with ambulacrum bearing a pair of claws and an empodium with two rows of tenent hairs. Counts of setae on legs I-IV, indicating additional solenidia in parenthesis: coxae: $3-1-2-2$, trochanters $1-1-1-1$, femora $4-3-2-2$, genua $1(\kappa)-1(\kappa)-1-1$, tibiae $9(\varphi)-8(\varphi)-8(\varphi)-7(\varphi)$, tarsi $10(\omega)-10(\omega)-8-8$.

\section{Remarks}

Neophyllobius tepoztlanensis sp. nov. resembles N. marginatus De Leon, 1958 collected from an undetermined composite plant and Quercus sp. in Nayarit, Mexico. In both species, the dorsal setae on genua I-IV are short, less than half as long as tibiae I-IV; the setae on femur I are short (about a quarter of the length of the podomere). These species can be differentiated by the following characters: in $N$. tepoztlanensis sp. nov., dorsal setae $c l$ as long as setae $d l$, and setae $v$ " on femora I-II positioned distinctly in front of $v^{\prime}$. In $N$. marginatus, dorsal setae $c l$ about half as long as seta $d l$, and setae $v^{\prime}$ and $v$ ” on femora I-II are positioned horizontally on nearly the same level.

\section{Ecology}

Neophyllobius tepoztlanensis sp. nov. is deemed to be an inhabitant of the tree canopy and was found on Tillandsia schiedeana and T. hubertiana at $2.7 \mathrm{~m}( \pm 0.4)$ on Sapium macrocarpum.

\section{Distribution}

This species is only known from San Andrés de la Cal, Morelos, Mexico. The type locality of N. tepoztlanensis sp. nov. is about $600 \mathrm{~km}$ from Ixtlán del Río, Nayarit, Mexico and $660 \mathrm{~km}$ from Tepic, Nayarit, the two known localities of $N$. marginatus.

Neophyllobius tescalicola sp. nov. urn:1sid:zoobank.org:act:C58F130B-B7EC-423F-8AB5-EF5C0216EC0C

Fig. 6A-F

\section{Diagnosis}

This species is unique due to a combination of following characters: dorsal setae reaches setae immediately behind, femur II with three setae ( $d, v^{\prime}$ and $v$ '), femur III with two setae ( $d$ and $\left.v^{\prime}\right)$, setae $d$ on genua I-IV passing tibiae, long setae (about $1 / 3$ of podomere length) on femur I; setae $d$ on femur I positioned behind setae $l$ ', dorsal idiosomal setae $p d x$ and $c l$ grouped on small and finely-striated platelet.

\section{Etymology}

The specific name refers to the parent rock of the soil (lava flow) in which soil litter, the habitat of this mite species, is deposited. The word "tescal" in the náhuatl language means covered basalt stone from ancient volcanic eruptions or volcanic lava field, and the latin suffix "cola" means inhabitant (one who inhabits). So, tescalicola means "inhabitant of volcanic lava fields". 


\section{Type material}

\section{Holotype}

MEXICO: 9 , CNAC009247, on soil litter of Quercus obtusata. Collected from the type locality on 12 Mar. 2014, O. Cortés and R. Paredes coll. (RPL1224).

\section{Paratypes}

MEXICO: 2 우, CNAC009248, 1 q, CIUM, on soil litter of Quercus obtusata, 23 Oct. 2014, R. Reyes and R. Paredes coll. (RPL1317). All collected from the type locality, with same data as holotype except where noted.

\section{Type locality}

MEXICO: Morelos, Tepoztlán, 1 km S of San Andrés de la Cal, $18.94329^{\circ}$ N, $99.11784^{\circ}$ W, 1485 m a.s.l.

\section{Description}

Female $(n=3)($ Fig. $6 A-F)$

Holotype female (followed in parentheses by range of holotype and two paratype females).

Gnathosoma. 88 (85-90) long and 82 (80-85) wide. Subcapitulum with subcapitular setae $m 24$ (24-27) and two pairs of adoral setae $\operatorname{Or} 115(12-15)$ and $\operatorname{Or} 28(8)$; these three pairs nude and slender, $m$ longest (Fig. 6B); distance $m-m 22$ (20-23). Chelicerae 24 (23-25) long. Palp, five-segmented with following setal distribution: trochanter without setae; femur with two serrated setae, $d 16$ (15-16) and $l^{\prime} 27$ (2528 ); genu with one long, slender, nude dorsal $(d)$ seta 37 (35-38); tibia with three tactile setae (l', $l$ "' and $d$ ) and one claw (sword-like seta); tarsus with two eupathidia ( $a \mathrm{~cm} \zeta$ and sul $\zeta$ ), two simple setae ( $b a$ and $v a$ ) and one small solenidion $(\omega)$ (Fig. 6A). Setae elcp present.

IDIosoma. Longer than wide, 340 (330-345) long (gnathosoma excluded), 305 (300-310) wide. Cuticle striated, except on coxae and attenuated between setal pairs $p d x, c 1$ and $d 1$ (Fig. 6C-D). Dorsum. With 15 pairs of serrated setae set on small tubercles; all setal pairs longer than distance to setal pairs immediately behind, $e 2$ longest and $h 2$ shortest. Two pairs of eyes are positioned between setae $s c i$ and sce. Setal pairs $p d x$ and $c 1$ associated in a small and weakly striated platelet (Fig. 6C). Length of setae: $v i$ 81 (80-81), ve 77 (76-77), sci 70 (70), sce 77 (75-80), pdx 71 (70-73), cl 80 (80-83), c2 84 (84-85), dl 77 (75-77), d2 74 (74-75), el 84 (84-85), e2 87 (85-90), fl 84 (83-84), f2 40 (39-41), h1 45 (43-45), h2 36 (35-36). Distances between setae: vi-vi 53 (50-53), ve-ve 99 (99-100), vi-ve 36 (35-36), scisci 120 (120-125), sce-sce 160 (160-165), sci-sce 42 (40-43), cl-dl 53 (50-53), d1-d1 19 (18-19), $d 1-d 288$ (85-90), d1-el 54 (53-54), ve-sci 20 (18-20), pdx-pdx 20 (20), pdx-cl 26 (25-28), c1-cl 19 (18-20), c1-c2 91 (90-95), c2-c2 185 (180-185), el-el 12 (11-12), el-f1 37 (36-38), f1-h1 53 (53-55), el-e2 67 (65-67), d2-e2 54 (54-55), f1-f1 12 (12), fl-f2 56 (55-56), f2-f2 70 (70-73), e2-f2 68 (65-70), h1-h1 9 (9), hl-h2 23 (20-25), h2-h2 42 (40-43), f2-h2 28 (27-28). Venter. Coxal setae slenderer than dorsal setae. Setal pairs $1 a, 3 a, 4 a, a g, g, p s 1, p s 2$ and $p s 3$ nude and short. Setae $1 b$, $1 c, 2 c, 3 b, 3 c, 4 b$ and $4 c$ serrated. Setae $1 c$ longest and $p s 2$ shortest. Setal pairs $3 a$ and $4 a$ located on individual platelets. Genito-anal valves with one pair of genital setae $(g)$. Coxa I grouped with coxa II, and coxa III with IV but not completely fused (Fig. 6D). Length of setae: $1 a 29$ (28-29), $1 b 19$ (15-20), lc 58 (55-58), 2c 51 (50-55), 3a 21 (20-21), $3 b 27$ (27-30), 3c 30 (30), 4a 22 (20-22), 4b 26 (25-27), $4 c 30$ (30), ag 20 (20), g 14 (13-14), ps 114 (13-14), ps2 12 (11-12), ps3 14 (13-14).

LEGS. Slender and long, leg IV longest. Lengths (excluding ambulacra): leg I 660 (650-665), leg II 570 (565-580), leg III 660 (660-675), leg IV 750 (745-765). Podomere lengths: femur I 215 (210-215), femur II 170 (170-180), femur III 185 (185), femur IV 225 (220-230), tibia I 215 (210-220), tibia II 185 (180-190), tibia III 235 (230-235), tibia IV 265 (260-270), tarsus I 80 (80), tarsus II 82 (80-83), tarsus III 83 (81-84), tarsus IV 86 (86-90). Leg setae as indicated in Fig. 6E-F. Tarsi I with five setal 

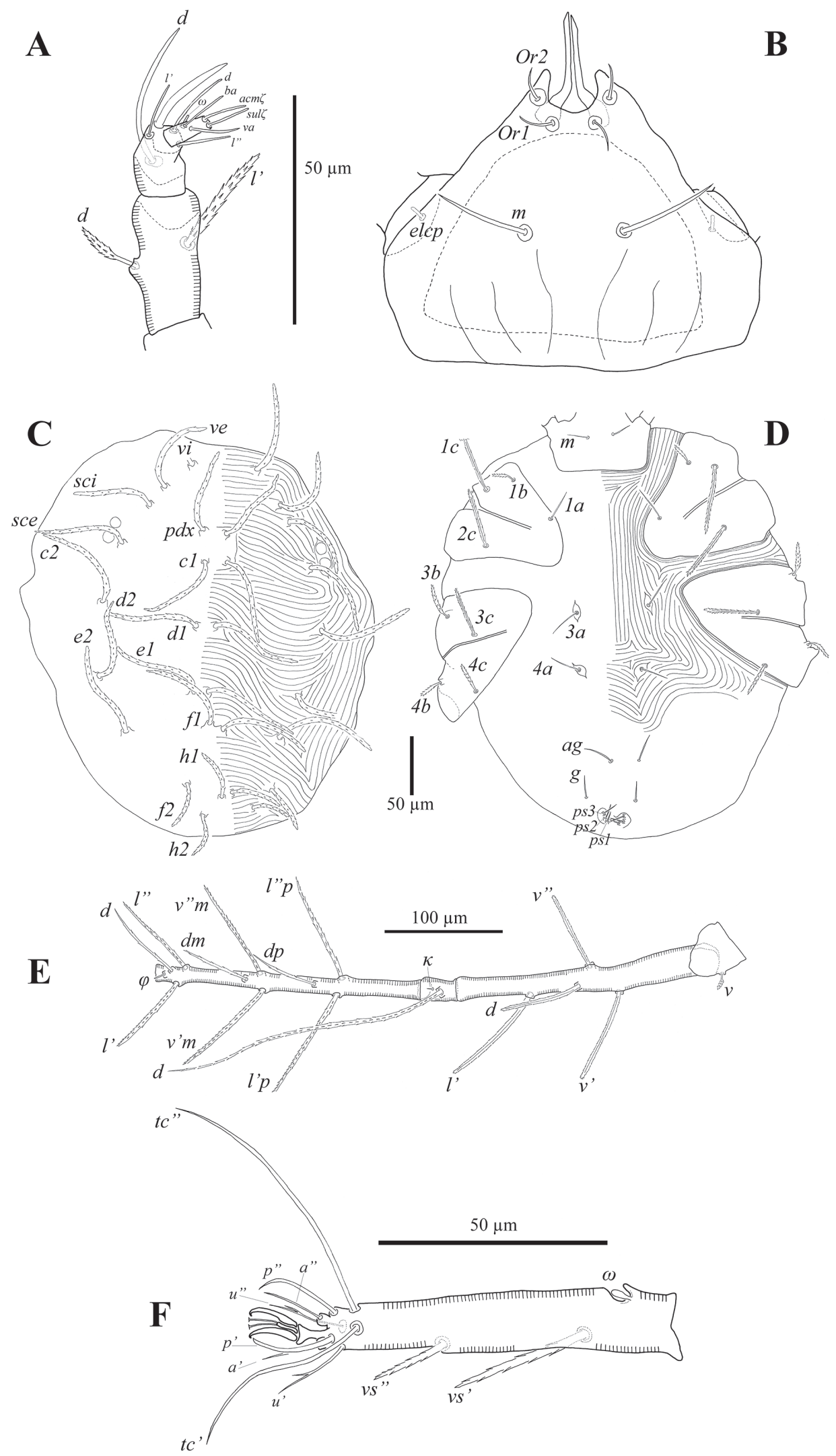

Fig. 6. Neophyllobius tescalicola sp. nov.,, , holotype. A. Palp. B. Subcapitulum. C. Dorsal idiosoma. D. Ventral idiosoma. E. Trochanter-tibia of leg I. F. Tarsus I. 
pairs: $v s$ serrated, $t c, a, p$ and $u$ slender and nude, $u$ bifurcated at tip. Setae $t c$ longest. Setae lengths: $v$ ' on femur I 80 (75-85), $v$ ”' on femur I 67 (65-70), l' on femur I 94 (94-98), $d$ on femur I 68 (65-70), dorsal seta on genu I 250 (245-250), dorsal seta on genu II 250 (250), dorsal seta on genu III 285 (280290), dorsal seta on genu IV 341 (340-345). All tarsi with ambulacrum bearing a pair of claws and an empodium with two rows of tenent hairs. Counts of setae on legs I-IV, indicating additional solenidia in parenthesis: coxae: $3-1-2-2$, trochanters $1-1-1-1$, femora $4-3-2-2$, genua $1(\kappa)-1(\kappa)-1-1$, tibiae $9(\varphi)-8(\varphi)-8(\varphi)-7(\varphi)$, tarsi $10(\omega)-10(\omega)-8-8$.

\section{Remarks}

Neophyllobius tescalicola sp. nov. resembles $N$. farrieri and $N$. cibyci sp. nov. In these three species, the dorsal setae on genua I-IV are very long, extending beyond the tip of the tarsus. These species can be differentiated by the following characters: in $N$. tescalicola sp. nov., setae on femur I are long, about $1 / 3$ of podomere length, setae $d$ on femur I is positioned behind setae $l^{\prime}$, dorsal idiosomal setae $p d x$ and $c l$ are grouped on a small and finely-striated platelet. In $N$. farrieri and $N$. cibyci sp. nov., setae on femur I are short, about a sixth of the length of the podomere, setae $l$ ' and $d$ on femur I are nearly positioned horizontally at same level, and dorsal idiosomal setae $p d x$ and $c l$ are not joined on a platelet.

\section{Ecology}

Neophyllobius tescalicola sp. nov. inhabits soil litter of Quercus obtusata, and was collected in dry (March) and in rainy seasons (October).

\section{Distribution}

This species is only known from the type locality.

\section{Key to the species of the genus Neophyllobius in Mexico}

Based on females, updated from De Leon (1958).

1. Dorsal setae $c l, d 1, e l$ and $f 1$ not reaching setae immediately behind

Neophyllobius mexicanus McGregor, 1950

- At least one of these dorsal setae $c 1, d 1, e l$ and $f 1$ reaching or extending beyond the seta immediately behind

2. Femur II with four setae

N. quadrisetosus De Leon, 1958

- Femur II with three setae 3

3. Femur III with three setae N. trisetosus De Leon, 1958

- Femur III with two setae.

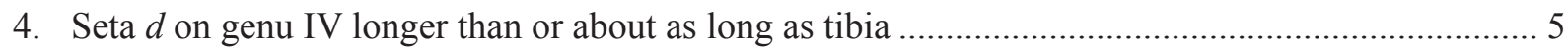

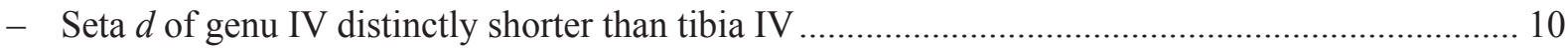

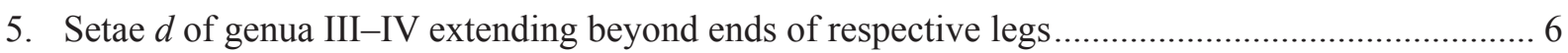

- Setae $d$ of genua III-IV not extending beyond ends of respective legs........................................... 8

6. Femur I with long setae, about $1 / 3$ of podomere length; setae $l$ ' on femur I positioned before setae $d$; dorsal idiosomal setae $p d x$ and $c 1$ grouped on a small and finely striated platelet

Neophyllobius tescalicola sp. nov.

- Femur I with short setae, about $1 / 6$ of podomere length; setae $l$ ' and $d$ on femur I positioned horizontally nearly at same level; dorsal idiosomal setae $p d x$ and $c 1$ not joined on a platelet 
PAREDES-LEÓN R. et al., New species of camerobiid mites and setal homology in Neophyllobius

7. Length of dorsal setae $c l$ and $d l$ same as distance between setae $c l-d l$ and $d l-e l$ respectively; setae $e l$ longest of dorsal setae; setae $d$ and $l$ ' on palpal femur, weakly spinose.... N. farrieri De Leon, 1958

- Dorsal setae $c l$ and $d l$ distinctly longer than distance between setae $c 1-d 1$ and $d 1-e 1$ respectively; setae $d l$ longest of dorsal setae; setae $d$ and $l$ ' on palpal femur, heavily spinose

Neophyllobius cibyci sp. nov.

8. Seta $d$ of genu III distinctly shorter than tibia III

N. inequalis De Leon, 1958

- Seta $d$ of genu III longer than or about as long as tibia III

9. Seta $d$ on genu II shorter than tibia II, seta of genu III about as long as tibia III

N. equalis De Leon, 1958

- Setae $d$ on genua II and III distinctly longer than respective tibiae... N. consobrinus De Leon, 1958

10. Striae of dorsum consisting chiefly of broken striae; posterior margins of femora I-IV, highly serrulate

N. lobatus De Leon, 1958

- Striae of dorsum consisting chiefly of unbroken striae; posterior margins of femora, not highly serrulate.

11. Dorsal setae $d 1$ more than half as long as width of body; seta $d$ on genu III about two-thirds as long as tibia III.

N. deleoni Bolland, 1991

- Dorsal setae $d l$ less than half as long as width of body; seta $d$ on genu III about one-half (or less) as long as tibia III

12. Seta $d$ on genu II distinctly longer than genu II

- Seta of genu II about as long as or shorter than genu II .............................................................. 15

13. Seta $d$ on genu II nearly as long as seta of genu III and about half as long as seta of genu IV ....... 14

- Seta $d$ on genu II about half as long as seta of genu III and about one-third as long as seta $d$ on genu IV

N. longulus De Leon, 1958

14. Dorsal setae $c l$ as long as setae $d 1$; setae $v^{\prime \prime}$ on femora I-II distinctly in front of $v^{\prime}$......

Neophyllobius tepoztlanensis sp. nov.

- Dorsal setae $c l$ about half as long as setae $d 1$; setae $v$ on femora I-II positioned horizontally on nearly same level

N. marginatus De Leon, 1958

15. Genual setae coarse, setiform, distinctly spinose

N. curtipilus De Leon, 1958

- Genual setae linear (seta of genu II is slightly obovate), very faintly spinose

N. spatulus De Leon, 1958

\section{Discussion}

Some patterns of setal ontogeny found in Neophyllobius cibyci sp. nov. have also been found in other Raphignathina. For example, the presence of setae $v$ on trochanters I-III, retarded until the protonymphal instar, was also reported in Caligonellidae (Swift 2001) and Pterygosomatidae (Paredes-León \& Guzmán-Cornejo 2015).

The larva of $N$. cibyci sp. nov. bears the setal pair $p$ (i.e., $p$ ' and $p$ ") on tarsus I instead of only $p^{\prime}$ as in Neophyllobius sp. (Swift 2001). Also, tarsus IV in females of N. cibyci sp. nov. has one more seta (i.e., eight instead of seven like Neophyllobius sp.); however, Swift (2001) didn't mention the nomenclature of these seven setae, making the comparison with $N$. cibyci sp. nov. difficult. Another difference between both species is the presence of iteral setae (it) on tarsi I-IV located anterodorsal to (tc) (Swift 2001). Based on the location (anterodorsal to $t c$ ), we consider setae it to be absent in $N$. cibyci sp. nov., but setal 
pair $p$ to be present instead. The same condition (i.e., presence of setal pair $p$ on tarsi I-IV instead of setal pair it) was reported by Fan \& Walter (2011) for Acamerobia inflatus (Camerobiidae).

The presence of setal pair $i t$ has been reported anterodorsal to setal pair $p$ and $a$ for some pterygosomatid mites (Pterygosomatidae) only in tarsus I (Bochkov et al. 2008; Paredes-León et al. 2012; ParedesLeón \& Guzmán-Cornejo 2015). According to Khanjani et al. (2014), setal pair it is also absent in Neophyllobius ostovani Khanjani, Hoseini, Yazdanpanah \& Masoudian, 2014, and in N. lorestanicus Khanjani, Hoseini, Yazdanpanah \& Masoudian, 2014 adults. Compared with these latter species, Neophyllobius cibyci sp. nov. has both setae of pair $p$ (i.e., $p$ ' and $p^{\prime \prime}$ ) on tarsi I-II, whereas N. ostovani has only one ( $\left.p^{\prime}\right)$ on tarsi I-II. $N$. lorestanicus has both setae $p$ on tarsus I but only $p$ ' on tarsus II.

In many other species of the genus Neophyllobius the counts of setae in adults, from coxa to tarsus, appears to be consistent with that found in Neophyllobius cibyci sp. nov. (coxae: 3-1-2-2, trochanters 1-1-1-1, femora 4-3-2-2, genua $1(\kappa)-1(\kappa)-1-1$, tibiae $9(\varphi)-8(\varphi)-8(\varphi)-7(\varphi)$, tarsi $10(\omega)-10(\omega)-8-8)$, such as N. lachishensis Bolland, 1998, N. piniphilus, N. demirsoyi Akyol \& Koç, 2006 and N. quercus Uluçay \& Koç, 2014, among others (Bolland 2001; Akyol \& Koç 2006; Uluçay \& Koç 2014).

Leg setation teratologies similar to that shown by $N$. cibyci sp. nov. has also been reported in other camerobiid mites, for example in N. consobrinus (Bolland \& Swift 2000), Tycherobius stramenticola Bolland, 1986 and T. polonicus Bolland, 1986 (Koç \& Akyol 2007). In the last two species, abnormal disposition of setae are also found in dorsal and ventral idiosoma (Koç \& Akyol 2007).

Due to the lack of setal notations, and because many descriptions of camerobiid mites are based on single specimens, it is very difficult to establish a homology hypothesis among instars and even among species. Notwithstanding this fact, our data suggest a hypothesis to how leg setae appear at different life stages on the podomeres of legs I-IV of larva, protonymph and adult. However, a detailed examination of the leg chaetotaxy of taxa in Camerobiidae will have to be conducted to establish homologies within the family and with the other raphignathoids.

The results presented here clearly show that the species richness of the family Camerobiidae in Mexico is under-represented, and that systematic surveys sampling different components of vegetation are needed. The species recorded had different habitat preferences, two of them inhabiting epiphytic bromeliads on two tree species at an average height of $2.8 \mathrm{~m}( \pm 0.4)$, and one inhabiting soil litter of one tree species. This suggests that habitat diversity determines the richness of the group but it needs to be studied in greater detail.

\section{Acknowledgements}

We are grateful to O. Cortés-Anzúres, S. Gómez-Rosas and R. Reyes (CIByC) for field assistance. Thanks to T.M. Pérez and G. Montiel-Parra (CNAC) for allowing us to carry out acarological procedures in their laboratory. Thanks to J.R. Ramírez-Rodríguez and G. Flores-Franco (CIByC) for lending us their optic microscope. Thanks to D.E. Walter and Q-H. Fan (Ministry for Primary Industries, Auckland, New Zealand) for their comments on leg chaetotaxy in camerobiid mites. Thanks to J.A. Ballesteros (George Washington University) and E.A. Ueckermann (Agricultural Research Council, South Africa) for providing us with literature on camerobiid mites. Thanks to D. Ortíz and F. Chiang (Instituto de Biología, UNAM) for corroborating the correct formation of specific epithets in Latin. Thanks to Ian Gardner (The seven seas translations agency) for improving the English language. We are grateful to the editorial board of European Journal of Taxonomy, Koen Martens (Editor in Chief) and two anonymous reviewers for useful comments which improved this manuscript. This work was supported by the "Programa para el Desarrollo Profesional Docente para el tipo Superior-Secretaría de Educación Pública (PRODEP-SEP)" through a post-doctoral fellowship to the first author under grant PRODEP/103.5/13/9465; and "Red Temática de Colaboración de Cuerpos Académicos: Sistemática y ecología en comunidades forestales y cultivos" under grant PRODEP/103.5/09/1187, Folio 13. 
PAREDES-LEÓN R. et al., New species of camerobiid mites and setal homology in Neophyllobius

\section{References}

Akyol M. \& Koç K. 2006. The camerobiid mites (Acari, Camerobiidae) of Turkey. Biologia, Bratislava 61 (2): 125-132. http://dx.doi.org/10.2478/s11756-006-0020-1

Akyol M. 2013. Two new species of the genus Neophyllobius Berlese (Acari: Camerobiidae) from Turkey. International journal of Acarology 39 (7): 542-546. http://dx.doi.org/10.1080/01647954.2013.839741

Arizaga S., Martínez-Cruz J., Salcedo-Cabrales M. \& Bello-González M.A. 2009. Manual de la biodiversidad de encinos michoacanos. Secretaría de Medio Ambiente y Recursos Naturales and Instituto Nacional de Ecología, Mexico City.

Bochkov A.V., OConnor B.M. \& Wauthy G. 2008. Phylogenetic position of the mite family Myobiidae within the infraorder Eleutherengona (Acariformes) and origins of parasitism in eleutherengone mites. Zoologischer Anzeiger 247 (1): 15-45. http://dx.doi.org/10.1016/j.jcz.2006.12.003

Bolland H.R. 1983. A description of Neophyllobius aesculi n. sp. and its developmental stages (Acari: Camerobiidae). Entomologische Berichten 43 (3): 42-47.

Bolland H.R. 1986. Review of the systematics of the family Camerobiidae (Acari, Raphignathoidea). I. The genera Camerobia, Decaphyllobius, Tillandsobius, and Tycherobius. Tijdschrift Voor Entomologie 129: 191-215.

Bolland H.R. 1991. Review of the systematic of the family Camerobiidae, II. The genus Neophyllobius Berlese, 1886 (Acari: Raphignathoidea). Genus 2: 59-226.

Bolland H.R. \& Swift S.F. 2000. Hawaiian Raphignathoidea: Family Camerobiidae (Acariformes: Prostigmata), with descriptions of three new species. International Journal of Acarology 26 (4): 347356. http://dx.doi.org/10.1080/01647950008684209

Bolland H.R. 2001. Observations and description of Neophyllobius piniphilus n. sp. (Acari: Camerobiidae) from pine trees in The Netherlands. International Journal of Acarology 27 (2): 129-134. http://dx.doi. org/10.1080/01647950108684241

Cortés-Anzúres B.O. 2015. Distribución de epifitas entre forofitos de un bosque tropical caducifolio sobre suelo volcánico de Tepoztlán, Morelos, así como el efecto de Quercus obtusata y Sapium macrocarpum sobre la germinación de Encyclia spatella y Guarianthe aurantiaca. Master's thesis, Universidad Autónoma del Estado de Morelos, Cuernavaca.

De Leon D. 1958. The genus Neophyllobius in Mexico (Acarina: Neophyllobiidae). The Florida Entomologist 41 (4): 173-181. http://dx.doi.org/10.2307/3492958

De Leon D. 1967. Some Mites of the Caribbean Area. Part I. Acarina on Plants in Trinidad, West Indies. Allen Press Inc., Lawrence.

Espejo-Serna A., López-Ferrari A.R., Ramírez-Morillo I., Holst B.K., Luther H.E. \& Till W. 2004. Checklist of Mexican Bromeliaceae with notes on species distribution and levels of endemism. Selbyana 25: $33-86$.

Fan Q.-H. \& Walter D.E. 2011. Acamerobia inflatus gen. n. \& sp. n. from Australia (Acari: Prostigmata: Raphignathoidea: Camerobiidae) with notes on the idiosomal chaetotaxy. Zootaxa 3045: 45-56.

Gerson U., Smiley R.L. \& Ochoa R. 2003. Mites (Acari) for pest control. Wiley-Blackwell, London.

Grandjean F. 1941. La chaetotaxie comparée des pattes chez les oribates (1re série). Bulletin de la Societé Zoologique de France 66: 33-50.

Grandjean F. 1944. Observations sur les Acariens de la famille des Stigmaeidae. Archives des Sciences physiques et naturelles 26: 103-131. 
Grandjean F. 1946. Au sujet de l'organe de Claparede, des eupathides multiples et des taenidies mandibulaires chez les Acariens actinochitineux. Archives des Sciences physiques et naturelles 28: 63-87.

Hoffmann A. \& López-Campos G. 2000. Biodiversidad de los ácaros en México. Comisión Nacional para el Conocimiento y Uso de la Biodiversidad and Universidad Nacional Autónoma de México, Mexico City.

Kethley J. 1990. Acarina: Prostigmata (Actinedida). In: Dindal D.L. (ed.) Soil biology guide: 667-756. Wiley, New York.

Khanjani M. \& Ueckermann E.A. 2006. A new species of the genus Neophyllobius Berlese (Acari: Camerobiidae) from Iran. International Journal of Acarology 32 (3): 277-281. http://dx.doi. org/10.1080/01647950608684468

Khanjani M., Fayaz B.A. \& Ghanbalani G.N. 2010. Two new species of the genus Neophyllobius Berlese (Acari: Camerobiidae) from Iran. Zootaxa 2521: 53-64.

Khanjani M., Asadabadi A., Izadi H. \& Doğan S. 2012a. A new species of Neophyllobius (Acari: Raphignathoidea, Camerobiidae) from southeast Iran. Systematic and Applied Acarology 17 (1): 67-73. http://dx.doi.org/10.11158/saa.17.1.12

Khanjani M., Yazyanpanah S., Ostovan H. \& Fayaz B.A. 2012b. Three new species of the genus Tycherobius Bolland (Acari: Camerobiidae) from Iran. Zootaxa 3266: 23-40.

Khanjani M., Hajizadeh J., Hoseini M.A. \& Jalili M. 2013. Two new species of the genus Tycherobius Bolland (Acari: Camerobiidae) from north of Iran. International Journal of Acarology 39 (2): 130-139. http://dx.doi.org/10.1080/01647954.2012.752405

Khanjani M. \& Hoseini M.A. 2013. Three new species of the genus Neophyllobius Berlese (Acari: Camerobiidae) from southern and southwestern Iran. Zootaxa 3666: 510-522. http://dx.doi.org/10.11646/ zootaxa.3666.4.6

Khanjani M., Hoseini M.A., Yazdanpanah S. \& Masoudian F. 2014. Neophyllobius lorestanicus sp. nov. and N. ostovani sp. nov. (Acari: Camerobiidae) from Iran. Zootaxa 3764: 441-454. http://dx.doi. org/10.11646/zootaxa.3764.4.4

Koç K. \& Ayyildiz N. 1996. A new species of Neophyllobius Berlese (Acari: Camerobiidae) from Turkey. International Journal of Acarology 22 (4): 291-294. http://dx.doi.org/10.1080/01647959608684107

Koç K. \& Akyol M. 2007. Morphometric \& intraspecific variations between specimens of Tycherobius stramenticola and Tycherobius polonicus (Acari: Camerobiidae) from Turkey. Acarologia 47 (3-4): $139-142$.

McGregor E.A. 1950. Mites of the genus Neophyllobius. Bulletin of the Southern California Academy of Sciences 49 (2): 55-70.

Norton R.A. 1977. A review of F. Grandjean's system of leg chaetotaxy in the Oribatei and its application to the Damaeidae. In: Dindal D.L. (ed.) Biology of oribatid mites: 33-62. SUNY College of Environmental Science and Forestry, New York.

Palacios-Vargas J.G. 1982. Microartrópodos asociados a bromeliáceas. In: Salinas P.J. (ed.) Zoología Neotropical, Actas del VIII Congreso Latinoamericano de Zoología. Vol. 1: 535-545. Consejo Nacional de Investigaciones Científicas y Tecnológicas, Mérida.

Paredes-León R. \& Guzmán-Cornejo C. 2015. A new species of pterygosomatid mite and its phylogenetic position within the genus Geckobiella (Acariformes: Prostigmata: Pterygosomatidae). International Journal of Acarology 41 (1): 19-30. http://dx.doi.org/10.1080/01647954.2014.988642 
PAREDES-LEÓN R. et al., New species of camerobiid mites and setal homology in Neophyllobius

Paredes-León R., Klompen H. \& Pérez T.M. 2012. Systematic revision of the genera Geckobiella Hirst, 1917 and Hirstiella Berlese, 1920 (Acari: Prostigmata: Pterygosomatidae) with description of a new genus for American species parasites on geckos formerly placed in Hirstiella. Zootaxa 3510: 1-40.

Ruiz-Cordova J.P., Toledo-Hernández V.H. \& Flores-Palacios A. 2014. The effect of substrate abundance in the vertical stratification of bromeliad epiphytes in a tropical dry forest (Mexico). Flora 209 (8): 375-384. http://dx.doi.org/10.1016/j.flora.2014.06.003

Swift S.F. 2001. The leg chaetotaxy of Caligonellidae (Prostigmata: Raphignathoidea). In: Halliday R.B., Walter D.E., Proctor H.C. \& Colloff M.J. (eds) Acarology: Proceedings of the $10^{\text {th }}$ International Congress: 242-249. CSIRO Publishing, Melbourne.

The GIMP team. 2014. GIMP 2.8.14. Available from http://www.gimp.org [accessed 9 Aug. 2015]

Uluçay İ. \& Koç K. 2014. A new species of Neophyllobius and description of male of Neophyllobius yunusi (Acari: Camerobiidae) from Turkey. International Journal of Acarology 40 (1): 15-22. http:// dx.doi.org/10.1080/01647954.2013.870226

Vázquez M.M., Pereira A., Fragoso P. \& Rodríguez J.A. 2011. Riqueza y biodiversidad de organismos edáficos del Corredor Biológico Mesoamericano (México, Belice y Guatemala). In: Delgado Blas V.H., Ortegón Aguilar J.S., Vázquez González M.M., González Damián A. \& Hernández-Rodríguez J. (eds) Avances de ciencia y tecnología en Quintana Roo: 37-70. Plaza y Valdés, Mexico City.

Vázquez-González M.M. 2008. Microartrópodos edáficos litorales. Dugesiana 15: 7-15.

Vergara-Torres C.A., Pacheco-Álvarez M.C. \& Flores-Palacios A. 2010. Host preference and host limitation of vascular epiphytes in a tropical dry forest of central Mexico. Journal of Tropical Ecology 26 (6): 563-570. http://dx.doi.org/10.1017/S0266467410000349

Walter D.E., Lindquist E.E., Smith I.M., Cook D.R. \& Krantz G.W. 2009. Order Trombidiformes. In: Krantz G.W. \& Walter D.E. (eds) A manual of Acarology, 3' edition: 233-420. Texas Tech University Press, Texas.

Zeity M. \& Gowda C.C. 2013. A new species of Neophyllobius (Acari: Camerobiidae) from India. International Journal of Acarology 39 (7): 547-550. http://dx.doi.org/10.1080/01647954.2013.844726

Zhang Z.-Q., Fan Q.-H., Pesic V., Smit H., Bochkov A.V., Khaustov A.A., Baker A., Wohltmann A., Wen T., Amrine J.W., Beron P., Lin J., Gabrys G. \& Husband R. 2011. Order Trombidiformes Reuter, 1909. In: Zhang Z.-Q. (ed.) Animal biodiversity: An outline of higher-level classification and survey of taxonomic richness. Zootaxa 3148: 129-138.

Manuscript received: 16 October 2015

Manuscript accepted: 27 January 2016

Published on: 2 June 2016

Topic editor: Koen Martens

Desk editor: Charlotte Thionois

Printed versions of all papers are also deposited in the libraries of the institutes that are members of the EJT consortium: Muséum national d'Histoire naturelle, Paris, France; Botanic Garden Meise, Belgium; Royal Museum for Central Africa, Tervuren, Belgium; Natural History Museum, London, United Kingdom; Royal Belgian Institute of Natural Sciences, Brussels, Belgium; Natural History Museum of Denmark, Copenhagen, Denmark. 